Research Report No. 28/2007

\title{
Healing Fair Dealing?: A Comparative Copyright Analysis of Canadian Fair Dealing to UK Fair Dealing and US Fair Use
}

Giuseppina D'Agostino

Osgoode Hall Law School of York University, gdagostino@osgoode.yorku.ca

Follow this and additional works at: http:// digitalcommons.osgoode.yorku.ca/clpe

\section{Recommended Citation}

D'Agostino, Giuseppina, "Healing Fair Dealing?: A Comparative Copyright Analysis of Canadian Fair Dealing to UK Fair Dealing and US Fair Use" (2007). Comparative Research in Law \& Political Economy. Research Paper No. 28/2007.

http://digitalcommons.osgoode.yorku.ca/clpe/244 


\section{Giuseppina D' Agostino}

Healing Fair Dealing? A Comparative Copyright Analysis of Canadian Fair Dealing to UK Fair Dealing and US Fair Use

EDTORS: Peer Zumbansen (Osgoode Hall Law School, Toronto, Director, Comparative Research in Law and Political Economy, York University), J ohn W. Cioffi (University of California at Riverside), Lindsay Krauss (Osgoode Hall Law School, Toronto, Production Editor) 

CLPE Research Paper 28/2007

Vol. 03 No. 04 (2007)

\title{
Giuseppina D’Agostino
}

\section{Healing Fair Dealing? A Comparative Analysis of CANADIAN FAIR DEALING TO UK FAIR DEALING AND US FAIR USE}

\begin{abstract}
As a result of the March 4, 2004 Supreme Court of Canada decision in CCH Canadian Ltd v Law Society of Upper Canada for the first time in Canadian copyright history, the court determined that Canadian law must recognize a "user right" to carry on exceptions generally and fair dealing in particular. This paper compares the Canadian fair dealing legislation and jurisprudence to that of the UK and the US. It is observed that because of $\mathrm{CCH}$, the Canadian common law fair dealing factors are more flexible than those entrenched in the US. For the UK, certain criteria have emerged from the caselaw consonant to Canada's pre$\mathrm{CCH}$ framework and in many ways there is now a hierarchy of factors with market considerations at the fore. The real differences, however, ultimately lie in the policy preoccupations held by the respective courts, with Canada's top court alone concerned in championing user rights above all other rights. The paper concludes that Canadian fair dealing does not require too much healing but would benefit from some remedies outside (and complimentary to) the law and the courts. While doing nothing does not seem to be the appropriate response, legal intervention as many advocate may not be warranted either. Rather than, or at the very least together with, reforming the law, establishing fair dealing best practices is most promising. The parties directly affected in a specific industry can together develop these guidelines to ultimately aid in clearer and ongoing fairer fair dealing decision-making in the courts. It is here that US initiatives can serve as most fruitful to emulate.
\end{abstract}

Keywords: copyright, fair dealing, fair use, comparative law

JEL classification: K39

Author Contact: Giuseppina D’Agostino 
Assistant Professor, Osgoode Hall Law School

York University, 4700 Keele St.

Toronto, Ontario, Canada M3J 1P3

gdagostino@osgoode.yorku.ca 


\title{
HEALING Fair DEALING? A CoMparative COPYRIGHT ANALYSIS OF CANADIAN FAIR DEALING TO UK FAIR DEALING AND US FAIR USE
}

\author{
Giuseppina D’Agostino*
}

\section{INTRODUCTION}

As a result of the March 4, 2004 Supreme Court of Canada decision in CCH Canadian Ltd v Law Society of Upper Canada ${ }^{1}$ for the first time in Canadian copyright history, the court determined that Canadian law must recognize a "user right" to carry on exceptions generally and fair dealing in particular. Whereas the notion of exceptions before this decision was premised on a narrow interpretation of the scope of the exceptions, the Supreme Court has raised what was a narrow exception to the level of general principle. Thus, it is important in the ongoing project of copyright policy reform to probe the meaning of this ruling since it would affect potential policy work on exceptions, and especially how the notion of fair dealing is conceived and applied.

This paper proceeds in six parts. Part II examines the significance of $\mathrm{CCH}$ in rooting a user right. At this early juncture, it is useful to step back and revisit pre-CCH cases often seen as user unfriendly and then gaze forward into the post-CCH jurisprudential scene. Having set out the Canadian fair dealing legislative and jurisprudential landscape, the paper begins to explore this legal backdrop in other jurisdictions. UK fair dealing and US fair use are respectively examined in Parts III and IV. In discussing US fair use, particular attention is made to the flurry of criticism against it, with specific reference to the educational sector. Part $\mathrm{V}$ then compares the

\footnotetext{
* DPhil. Assistant Professor of Law, Osgoode Hall Law School, York University, Toronto, Canada. This paper is based on a study conducted for the Department of Canadian Heritage, Canada, June 2007. Usual disclaimers apply. This paper is a work in progress and comments are welcome at gdagostino@osgoode.yorku.ca.
}

${ }^{1}$ [2004] 1 SCR 339 (“CCH”). 
three jurisdictions. It is observed that because of $\mathrm{CCH}$, the Canadian common law factors are more flexible than those entrenched in the US. For the UK, certain criteria have emerged from the caselaw consonant to Canada's pre-CCH framework and in many ways there is now a hierarchy of factors with market considerations at the fore. The real differences, however, ultimately lie in the policy preoccupations held by the respective courts, with Canada's top court alone concerned in championing user rights above all other rights.

In the spirit of attaining copyright balance, some conclusions, by way of potential solutions, are advanced in Part VI. The main focus of this paper is on the applicable legislation and jurisprudence, although as will become apparent the solutions may (and should) also lie outside (and complimentary to) the realm of the law and the courts. While doing nothing does not seem to be the appropriate response, legal intervention may not be warranted either. Rather than, or at the very least together with, reforming the law, establishing fair dealing best practices is most promising. The parties directly affected in a specific industry can together develop these guidelines to ultimately aid in clearer and ongoing fairer fair dealing decision-making in the courts. It is here that US initiatives can serve as most fruitful to emulate.

While this paper investigates the legislative and jurisprudential landscape of fair dealing, it recognizes that there are other matters such as the role of contract and technology which also affect fair dealing/fair use. As argued elsewhere, the role of contract in copyright law cannot be underestimated. ${ }^{2}$ Contract law can promote and undermine fair dealing. Contracts can promote and undermine users and creators and any party in the copyright system for that matter. It is thus important to assess how the role of contract is embedded in the Canadian Copyright $\mathrm{Act}^{3}$ ("CCA") and how it

${ }^{2}$ The critical role of contract law in copyright law, or copyright contract is a recurring preoccupation of mine: G D'Agostino “Canada's Robertson Ruling: Any Practical Significance for Copyright Treatment of Freelance Authors?” [2007] EIPR 66; G D’Agostino "Freelance Authors for Free: Globalisation of Publishing, Convergence of Copyright Contracts and Divergence of Judicial Reasoning" in F Macmillan (ed) New Directions in Copyright (Edward Elgar Cheltenham 2005) 166 and G D'Agostino "Copyright Treatment of Freelance Work in the Digital Era" (2002) 19 Santa Clara Computer and High Technology LJ 37.

${ }^{3}$ Copyright Act RSC 1985 c C-42 (“CCA”). 
is deployed in practice to promote and temper the desired resultspresumably the objectives of balance where the interests of creators, users, rights holders and the general public are considered.

Moreover, the relationship between technology and fair dealing/fair use is equally material. Like contract, technology can also undermine and promote the various copyright stakeholder interests. The link between technology and fair dealing/fair use and other exceptions has been specifically examined in the US and the findings are negative. ${ }^{4}$ If fair dealing is to be preserved, then technologies cannot undermine its functioning. The CCA needs to be mindful of this dynamic. And so, while each of these matters are critical and will be raised throughout this paper where relevant, a fuller analysis is left for another time and place. Equally important and beyond the scope of complete analysis are the actual practices of stakeholders as for instance borne out in business models steadily evolving to embrace technology and promote the goals of easy and open access. The software open access movements and the Creative Commons are some models complementing some of the ethics of fair dealing. Last, because this paper is limited to the domestic and comparative aspects of fair dealing, it is at this time untenable to assess the international dimensions of the issue. Other scholars have begun to do so. ${ }^{5}$ For the immediate future, it does not seem as though $\mathrm{CCH}$ would be cause for concern in violating Berne's three-step test for instance. Should the courts apply $\mathrm{CCH}$ expansively, this may trigger international scrutiny of the legislation. To date, there have been no such conflicts.

\footnotetext{
${ }^{4}$ See text to nn 172-197.

${ }^{5}$ D Gervais “The Purpose of Copyright Law in Canada” (2005) UOTLJ 315-356.
} 


\section{FAIR DEALING IN CANADA}

\section{A. Legislative ConTEXT}

In Canada, the doctrine of fair dealing is statutorily entrenched in the CCA. Since its inception, fair dealing has been twice amended. ${ }^{6}$ Section 29 provides:

"Research or Private Study" (Section 29)

Fair dealing for the purpose of research or private study does not infringe copyright.

“Criticism or Review” (Section 29.1)

Fair dealing for the purpose of criticism or review does not infringe copyright if the following are mentioned:

(a) the source; and

(b) if given in the source, the name of the author, in the case of a work, performer, in the case of a performer's performance, maker, in the case of a sound recording, or broadcaster, in the case of a communication signal.

"News Reporting” (Section 29.2)

Fair dealing for the purpose of news reporting does not infringe copyright if the following are mentioned:

(a) the source; and

(b) if given in the source, the name of the author, in the case of a work,

(ii) performer, in the case of a performer's performance,

(iii) maker, in the case of a sound recording, or

(iv) broadcaster, in the case of a communication signal.

\footnotetext{
${ }^{6}$ North American Free Trade Agreement Implementation Act SC 1993 c 44 s 64(1) in force January 1, 1994, as ss 27(2) (a.1); then by an Act to amend the Copyright Act SC 1997 c 24 s 18, in force September 1, 1997, as s 29.2 (which remains the current provision of the Act)
} 
Traditionally, scholars, practitioners and the courts have construed fair dealing as a defence to copyright infringement. To make out a defence, the defendant had to prove that: (1) the action fit within one of the enumerated purposes (eg research or private study, research or criticism and news reporting) (2) the action was fair and (3) in the case of the last two categories, there was acknowledgment of the source. Typically, the enumerated grounds were interpreted as exhaustive as any purpose not falling strictly within an enumerated ground infringed. ${ }^{7}$ However, as shown below, this may no longer be the case post $\mathrm{CCH}$.

The CCA also contains specific exceptions for educational institutions and libraries, archives, and museums (commonly referred to as LAMs) and photocopying in LAMs, archives, ephemeral recordings and person's with disabilities. $^{8}$ These exceptions are meant to be TRIPs compliant, as limitations and exceptions confined to "certain special cases which do not conflict with a normal exploitation of the work and do not unreasonably prejudice the legitimate interests of the right holder."9 Of note is that a court may rely on public interest grounds for allowing an otherwise infringing activity, but this common law power has been rarely exercised in Canada or in the UK, where it was invented. ${ }^{10}$

\footnotetext{
${ }^{7}$ Michelin v CAW Canada [1997] 2 FC 306 denying parody.

${ }^{8}$ CCA (n 3) ss $29.4-30.4$.

9 The Agreement on Trade Related Aspects of Intellectual Property Rights, Including Trade in Counterfeit Goods (15 Apr 1994) Marrakesh Agreement Establishing the World Trade Organization, Annex 1C, Legal Instruments-Results of the Uruguay Round vols 31-33 ILM 1197 (“TRIPS”) art 13 incorporating art 9(2) of the Berne Convention for the Protection of Literary and Artistic works (9 Sept 1886) 168 Consol TS 1853 (the socalled "three-step test).

10 D Vaver “Canada’s Intellectual Property Framework: A Comparative Overview” (2004) 17 IPJ 125, 149; the defence only gained judicial notice once in Canada in R v James Lorimer \& Co [1984] 1 FC 1065 (CA) in relation to Crown copyright, but was not ultimately applied.
} 


\section{B. ANALYZING $C C H$}

\section{CCH CANADiAn LTD V LAW SOCIETY OF UPPER CANADA}

In CCH, a unanimous Supreme Court ruled that the Law Society of Upper Canada did not infringe copyright as its Great Library request-based reproduction services fell squarely within the allowances of the fair dealing doctrine. At issue were the single copies of reported decisions, case summaries, statutes, regulations and text selections reproduced pursuant to the Great Library Access Policy. ${ }^{11}$ According to the court, section 29 of the CCA, alongside the other exceptions, "must not be interpreted restrictively." ${ }^{2}$ The enumerated purposes should be accorded "large and liberal interpretation" in order to ensure that "users' rights" are not unduly constrained, and is not limited to non-commercial or private contexts. ${ }^{13}$ In this case, lawyers carrying on the business of law for profit were held to be conducting non-infringing research.

The court explained that to prove that a dealing was fair pursuant to CCA s 29, the defendant Law Society had the onus to prove (1) that the dealing was for the purpose of either research or private study and (2) that it was fair. Up to this point, the issues presented are consistent with those of a traditional fair dealing test in Canada and the UK.

As the court begins its analysis of the fair dealing doctrine-and drawing from UK and US approaches - it endorses certain factors which may be more or less relevant in future fair dealing cases. It also acknowledges that there may be other unnamed factors that could be used to assess the fairness of a dealing. Significantly, the court collapses an evaluation of whether the use could be construed as "research or private study" into the second analytical stage - whether the dealing was fair. In doing so, the first "hurdle" becomes one of the factors that is more or less relevant. In this way, the court softens the need to adhere to the traditional strictures of

\footnotetext{
${ }^{11}$ While the issue of authorization of copyright infringement was also material for the purposes of this paper, this issue will not be addressed.

${ }^{12}$ CCH (n 1) [48].

${ }^{13}$ ibid [51].
} 
proving fair dealing and puts into practice its assertion that the enumerated purposes require a liberal interpretation.

Below follows the court's six factors as construed and applied in the context of the case.

\section{a. PuRPose (AND COMMERCIAL NATURE) OF THE DEALING}

The court asserts that this first criterion "should not be given restrictive interpretation or this could result in undue restriction of users' rights."14 Courts should adopt an objective test to assess the users' real purpose or motive in using the copyrighted work. The Great Library's Access Policy states that its patrons making a request must delineate a legitimate purpose of use and where any ambiguity arises, the matter is referred to the Reference Librarian. For the court, this policy provided reasonable safeguards that the materials were being used for the purpose of research and private study.

The commercial nature of the dealing is an important considerationresearch done for commercial purposes may not be as fair as research done for research purposes. However, the court emphasizes that research is "not limited to non-commercial or private contexts." 15 While the court does not clearly state that commercial research is fair dealing, it states that it certainly can be.

\section{b. THE CHARACTER OF THE DEALING}

Here the focus is on how the works were dealt with, for instance multiple copies widely distributed can be unfair. In the Law Society's case this factor was met favourably: only single copies were made available to individual members of the legal profession. ${ }^{16}$ Further, if the copy is destroyed after it is used this may favour a finding of fairness. Courts can also consider the custom or practice in the industry to assess fairness. It is

\footnotetext{
${ }^{14}$ ibid [54].

15 ibid [51].

16 ibid [67].
} 
unclear whose perspective in the industry should be valued. Relying on custom can be dangerous since custom is often unilateral and often set by the party with the greater bargaining power. ${ }^{17}$ Arguably should the educators' or students' perspective be considered (who may be using works in an infringing fashion in certain circumstances) there could be fair dealing. Or alternatively, if the right holder's perspective is valued, custom could work against users. As the court did not expressly apply custom, it will be challenging to anticipate its applicability to future cases. Courts, of course, can (and should) rely on the existing body of caselaw in copyright and contract law to assess custom. ${ }^{18}$ The custom is implied by "the custom of a locality or by the usage of a particular trade" and "must be strictly proved." 19

\section{c. THE AMOUNT OF THE DEALING}

This factor seems to be a weaker consideration. The logic goes like this: the larger the taking the less the fair dealing. But of course, in several circumstances, as in the case of photographs it may be impossible to deal fairly with the work without copying the entire work. The court notes that for the purpose of research and private study it may be essential to copy an "entire academic article or an entire judicial decision."20 This wholesale inclusion would not likely be the case for the purposes of criticism or review in the case of literature. Research and private study is thus accorded wider scope under the court's reading of fair dealing. On the amount of the dealing, the court relied on the Great Library's Access Policy that it would exercise discretion to ensure fair dealing. In most

\footnotetext{
${ }^{17}$ As seen in the case of freelance journalists and their publishers in Canada where publishers relied on their "custom" to justify digital reproduction of the authors' works without the authors’ permission or due payment; see G D’Agostino (2007) (n 3).

${ }^{18}$ G D’Agostino "Anticipating Robertson: Defining Copyright Ownership of Freelance works in New Media” (18)(1) Cahiers de Propriété Intellectuelle 2006 tr « En attendant Robertson : Définir la possession du droit d'auteur sur les œuvres des pigistes dans les nouveaux médias » 166.

${ }^{19}$ This high standard requires that the custom is (1) notorious, (2) as certain as a written contract, and (3) reasonable: Beatson Anson's Law of Contract $\left(28^{\text {th }}\right.$ edn OUP Oxford 2002) 151.

${ }^{20} \mathrm{CCH}(\mathrm{n} 1)[56]$.
} 
occasions, only one judgment was copied and for secondary materials, when the requested amount was more than 5 per cent, a request could be refused. There was no evidence that the Great Library received and supplied multiple copy requests.

\section{d. Alternatives to the DeAling}

Here two criteria may lead a court against a fair finding where (a) there was a non-copyrighted work available as an alternative and (b) where the use of the copyrighted work was not reasonably necessary to achieve the "ultimate purpose."21 For instance, criticism could be equally effective by not actually reproducing the copyrighted work-this may weigh against fair dealing. ${ }^{22}$

In $\mathrm{CCH}$, the court remarks that there were no alternatives to the Great Library's photocopying service as (1) twenty per cent of the Great Library patrons were outside Toronto and (2) researchers were not allowed to borrow materials from the Great Library, thus justifying the need for copying. ${ }^{23}$ Curiously, the court focuses more on the ease to access the works, than on the actual availability of non-copyrighted works.

The court posits that the availability of a licence is irrelevant to weighing whether there were alternatives to the dealing. Accordingly, only because a user failed to obtain a licence should not be interpreted as proof that the dealing was not fair. If this were the case, the owners' monopoly would be extended beyond the objective of balance in the CCA. As such, if a dealing clearly falls into fair dealing in the first place, that dealing should not be subject to a licence. This analysis seems consonant with several stakeholder positions within the educational community that there exists a

${ }^{21}$ ibid.

${ }^{22}$ A comparative instance of this is in Hyde Park Residence Ltd v Yelland and others [2001] Ch 143 (CA) ("Hyde Park") [40] where publishing photographs of Lady Diana was merely gratuitous; having described any relevant portion of the photos would have sufficed and did not require reproduction.

${ }^{23}$ CCH (n 1) [69]. 
clear for fear culture to obtain often unnecessary licences out of excessive caution. $^{24}$

\section{e. NATURE OF THE WORK}

According to the court if the work is unpublished, the dealing may be more fair "in that its reproduction with acknowledgement could lead to a wider public dissemination of the work." 25 While the court remarks that this would serve one of the goals of copyright it is nonetheless a departure from previous Canadian caselaw. Equally, as noted below, this reasoning is contrary to the UK and US caselaw. ${ }^{26}$ The court suggests that protecting the author and furthering wide public dissemination are two conflicting objectives. One cannot further public dissemination if the priority is to protect (and presumably reward) the author. One factor that may soften this anti-author perspective is if the work in question were confidential in nature. ${ }^{27}$

24 In Canada, see CMEC "Copyright in Education" <http://cmec.ca/copyright/copyInternet.en.stm> (last visited June 29, 2007); M Wilkinson "Filtering the Flow from the Fountains of Knowledge" Ch 12 in M Geist (ed) In the Public Interest (Irwin Law Toronto 2005) 331. In the US: W Fisher et al "The Digital Learning Challenge: Obstacles to Educational Uses of Copyrighted Material in the Digital Age - A Foundational White Paper” Harvard Law School Research Publication No 2006-09 (Berkman Center for Internet and Society) <http://cyber.law.harvard.edu/media/files/copyrightandeducation.html> (visited 29 June 2007) ("White Paper”); J Urban and L Quilter "Efficient Process or 'Chilling Effects?' Takedown Notices Under Section 512 of the DMCA" $<$ http://static.chillingeffects.org/Urban-Quilter-512-summary.pdf> (visited 29 June 2007) (“Chilling Effects”).

${ }^{25}$ CCH (n 1) [58].

26 In US they went as far as developing a presumption against fair dealing for unpublished works see Harper \& Row Publishers, Inc v Nation Enterprises 471 US 539 (SCt 1985) 546; later overruled in Fair Use of Unpublished Works Publ No 102-492 (1992) 102d Cong 2d Sess, 106 Sat 3145 codified at 17 USC 107; in UK, see Hyde Park (n 22) and text to $\mathrm{n} 125$.

27 In Hyde Park (n 22)[40] the court considered that the works were subject to an agreement: "I do not believe that a fair minded and honest person would pay for the dishonestly taken driveway stills and publish them in a newspaper knowing that they had not been published or circulated...” 
The Great Library easily met this factor as the works in question were essential to legal research and were subject to its Access Policy stating that the patron's purpose to access the works must be for research, private study, criticism, review or use in legal proceedings. ${ }^{28}$

\section{f. EFFECT OF THE DEALING ON THE WORK}

If the work in question competes with the market of the original work it is less likely that the dealing will be found to be fair. In underscoring that the market factor "is neither the only factor nor the most important factor' the court seems to suggest that this factor is less important than the others. Interestingly, this "market substitute" factor seems to be more important in the $\mathrm{UK}^{29}$

There was no evidence advanced to indicate that there was an effect on the publishers' market. Rather, the publishers continued to produce new reporter series and other legal publications during the period of the Great Library's request-based copying. The court acknowledges that while the Law Society has the evidentiary burden, "it lacked access to evidence about the effect of the dealing on the publishers' market." 30 And so, this decision suggests that the onus may be reversed if the defendant cannot access market impact evidence. This seems fair as the publishers are often the more sophisticated parties in a better position to access such records, though potentially a tall order as it may involve crystal ball-gazing. ${ }^{31}$

\section{CCH OBSERVATIONS: USER-CENTRIC APPROACH}

From the analysis of the six factors it seems clear that the courts' penchant is pro-user. As further detailed below, this can be seen in particular in the

\footnotetext{
${ }^{28}$ CCH (n 1) [71].

${ }^{29}$ eg in Ashdown v Telegraph Group Ltd [2001] EWCA Civ 1142 (CA)[106] it is the most important factor.

${ }^{30} \mathrm{CCH}(\mathrm{n} 1)$ [72].

${ }^{31}$ See infra n 163.
} 
court's language, liberal interpretation of fair dealing, its elevated status of the doctrine as compared to other copyright exceptions, and its underlying policy preoccupations.

\section{a. DEFENCE TO USER RIGHT}

Even before $\mathrm{CCH}$, depending on the speaker's perspective, various terms were used to denote fair dealing such as "exceptions" "exemptions" "defences" or "user rights". ${ }^{32}$ Still, whereas in previous cases and as featured in almost every textbook, fair dealing was conceived of as a defence, $\mathrm{CCH}$ construes it more as a "right" and an "integral" part of copyright law. ${ }^{33}$

\section{b. EXPANDED PURPOSES}

$\mathrm{CCH}$ advocates for a liberal approach to interpreting the purposes of the dealing as these "should not be given restrictive interpretation." 34 In this sense, new purposes could be included under the enumerated grounds. Parody could be one of these. Significantly, the court considers the purposes of research under the first of six factors, "purposes (and commercial nature) of the dealing". The court thus seems to soften the rigidity of following the more traditional schematic approach (where it first assessed whether the use fell under the enumerated purpose and then examined fairness). Rather, the court collapses the first part of the "purposes" analysis into the second part-assessing fairness. As indicated below, here the court aligns itself with the more flexible US approach where there are no enumerated grounds, but an open list of purposes.

\footnotetext{
${ }^{32}$ Vaver (n 6) 148-49; P Esmail "CCH Canadian Ltd v Law Society of Upper Canada Case Comment on a Landmark Copyright Case” (2005) 10 Appeal 13-24 [17].

${ }^{33}$ For fair dealing as a defence pre CCH: see Allen v Toronto Star Newspapers Ltd (1997) 152 DLR $\left(4^{\text {th }}\right) 518$ [34]; for fair dealing as an exception: Boudreau v Lin 150 DLR $\left(4^{\text {th }}\right) 324$ (OCJ) Metivier J [48]; More recently, terms like "principle" have also been used: M Bouchard "The Copyright Board: A Review of Some Recent Issues and Future Challenges" (The Law Society of Upper Canada Entertainment, Advertising \& Media Law Symposium held in Toronto on April 27-28, 2007).

${ }^{34}$ CCH (n 1) [54].
} 


\section{c. EXPANDED WORKS}

$\mathrm{CCH}$ clarifies that entire court decisions, typically under Crown copyright, can be copied fully and fairly. Following this logic, this may be the case with other government works, such as statutes, reports, and press releases.

\section{d. EXCEPTIONS AND FAIR DEALING}

$\mathrm{CCH}$ favours parties relying on fair dealing over other exceptions. ${ }^{35}$ While counsel's arguments at the onset of CCH in 1993 were in large part conditioned by the lack of the existing "libraries, archives, museums" or "educational institutions" exceptions, the Supreme Court nonetheless emphasized that an applicable user can always rely on the fair dealing doctrine first: ${ }^{36}$ "It is IF when a library were unable to make out the fair dealing exception under s. 29 that it would need to turn to s. 30.2 of the Copyright Act to prove that it qualified for the library exemption."37 The court prefers the blessing of the fair dealing doctrine over reliance on specific exceptions. This may be because, fair dealing, as construed by the court, now allows for a more flexible framework.

\section{e. CONSTRUCTING FAIR DEALING—INFRINGEMENT, BURDEN OF PROOF AND AGENCY}

In a traditional copyright infringement suit, the plaintiff has the burden of proof to show infringement. The burden then shifts on the defendant to advance a defence. The court seems to alter this progression in two ways: (1) it skips over a traditional analysis of infringement and (2) it may shift the onus of proof on the plaintiff for disproving fair dealing.

\footnotetext{
${ }^{35}$ ibid. [49] "it is only if a library were unable to make out the fair dealing exception under s 29 that it would need to turn to s 30.2 of the Copyright Act to prove that it qualified for the library exemption”.

${ }^{36}$ ibid.

${ }^{37}$ CCH (n 1) [49].
} 
First, its discussion of infringement is limited to authorization of infringement which is a different analysis than the typical "substantial part doctrine" to infringement. Rather, having reasoned that there is no authorization, the court proceeds immediately into a fair dealing analysis by framing fair dealing as an exception to copyright. ${ }^{38}$ Second, the court may shift the onus of proof in two ways, as it reasons that: (a) To establish fair dealing, the defendant need not adduce evidence that every use of the provided material was conducted fairly but can rely on its own general practice. ${ }^{39}$ For instance, in the case of the Great Library, its internal Access Policy-to photocopy only for purposes of research, review, private study and criticism with a corresponding gate-keeper role by the Reference Librarian for the copying of substantial secondary sourceswas seen as sufficient to show that its own practices were research-based and fair and it need not have proven that each of its patrons dealt fairly with the supplied materials. ${ }^{40}$ It is worth asking whether it is fair for librarians to shoulder the burden to police fair dealing. On the other hand, following rigid rules (eg establishing copy quotas through legislation) while perhaps clearer to all parties, would be too restrictive and not entirely reflective of the realities and goals of user experiences. Indeed, imposing a copy quota is the approach taken in Australia where apparently no more than ten percent of a work can be copied. ${ }^{41}$ Also vesting librarians with this gate-keeping role may allow them to better prove fair dealing.

And (b) While the Law Society has the evidentiary burden, because it could not access market impact evidence on the publishing market, the court holds it more appropriate for the plaintiff publishers and not the defendant users to make the case that they were negatively affected. The court thus allows the Law Society the right to rely on the Great Library's

${ }^{38}$ ibid [51] "The fair dealing exception under s. 29..."

${ }^{39}$ ibid [63].

${ }^{40}$ Access Policy detailed at ibid [65].

${ }^{41}$ Exposure Draft Part 4 of the Copyright Amendment Bill 2006: Exceptions and other Digital Agenda Review Measures (October 2006). <http://www.copyright.org.au/pdf/acc/Submissions/x0605.pdf>(visited 29 June 2007)14; but see $\mathrm{K}$ Weatherall commentary that the Draft is crafted in such a bad way that it is unclear as to what it actually does: <http://weatherall.blogspot.com/2006/10/oncopyright-amendment-bill-and-ipods.html> (visited 29 June 2007). 
general practice to establish fair dealing, rather than having to adduce evidence. The court embraces the concept of agency. ${ }^{42}$ As illustrated in Tariff $22,{ }^{43}$ knowing of the potential of end user infringement, will not absent express knowledge of end user infringing activity be seen as the intermediary authorizing end user infringement.

\section{f. CAUTIONARY NOTE ON CCH USER-CENTRIC POLICY}

Any analysis of the state of copyright post- $\mathrm{CCH}$, must be rooted in an understanding of what the Supreme Court understands to be Parliament's policy objectives. The Supreme Court of Canada reaffirms its previous ruling in Théberge that the CCA has supposedly dual objectives: “...a balance between promoting the public interest in the encouragement and dissemination of works of the arts and intellect and obtaining a just reward for the creator..." 44 The court maintains that the judiciary "should strive to maintain an appropriate balance between these two goals." 45 The court suggests that when copyright law promotes the encouragement and dissemination of works of the arts and intellect this is in the public interest. For the court, the chief method of attaining this is to protect user rights. Rewarding the "creator" is an important part of Canada's so-called dualistic copyright objectives but presumably not as in the public interest.

CCH's skewed expression of balance and the objectives of copyright law is seen further in its discussion of the doctrine of originality. The court maintains that when courts lower the standard of originality, the balance tips more in favour of the author/creator at the loss of a robust public domain to foster future creative innovation. ${ }^{46}$ While this may certainly be plausible, more often than not, copyright assignments and therefore the role of contract law (where the owner steps into the creator's shoes) allows for this erosion. In other words, understanding the dynamic relationship

\footnotetext{
${ }^{42}$ Consistent with Wilkinson's analysis (n 24) 346.

${ }^{43}$ SOCAN v CAIP 2004 SCC 45 [88] also known as Tariff 22 decision (“Tariff 22”).

${ }^{44}$ CCH [10] citing Théberge v Galerie d’Art due Petit Champlain Inc [2002] 2 SCR 336 at [30- 31]

${ }^{45} \mathrm{CCH}$ [10].

${ }^{46}$ CCH (n 1) [24].
} 
between author and owner is also important when accounting for future innovation and a robust public domain.

This perhaps ill-conceived copyright policy is matched by equally illconceived language. The court juxtaposes the public v. the creator in grounding its objectives, but in framing the issues it states: "this case requires this Court to interpret the scope of both owners' and users' right under the Copyright Act..." ${ }^{47}$ While the court notes the "creator" in its discussion of balancing copyright objectives, the court matter-of-factly replaces her with the term "owner" in the framing of the issues. Creators and owners are not the same category of stakeholders for the purposes of copyright. ${ }^{48}$ Their interests are often conflicting. One cannot easily replace them as if they were synonyms as the court and many commentators often do. Indeed, it is not entirely helpful when commentators argue that $\mathrm{CCH}$ has "shifted the focus of copyright law from the pro-author approach that had dominated in the past to a balanced approach that weighs the rights of the author against those of the user." 49 And that as a result, "the law in Canada is now that the courts must balance the interests of the authors of works against the public interest." 50 This is unfortunate copyright parlance in Canadian CCH commentary, and copyright generally. ${ }^{51}$

So while finally laudable that the court champions user rights, long forgotten by Canadian legislatures and the judiciary, where do creators fit in $\mathrm{CCH}$ ? While the policy for creators is not central to $\mathrm{CCH}$ (perhaps because for the most part the case deals with judges as creators, not the (stereo)typical category of creators like musicians, freelance authors, bloggers and so on), this oversight may limit future "balanced" rulings. Would the court have reached a similar ruling if other categories of creators were at issue? Robertson $\mathrm{v}$ Thomson Corp, dealing with freelance

\footnotetext{
${ }^{47}$ ibid [13] [emphasis added].

${ }^{48}$ As repeatedly argued in each of the noted publications at G D’Agostino (n 3).

${ }^{49}$ Esmail (n 32) [3].

50 ibid [31].

${ }^{51}$ But see M Geist "Strongest pro-user rights decisions in the world” Law Bytes Toronto Star (22 March 2004) available at <www.michaelgeist.ca> where he interprets CCH as attempting to balance user rights against those of owners and creators.
} 
authors, may decide such an issue, but the new trial is yet to make its way in the courts. ${ }^{52}$ In $\mathrm{CCH}$, judges and lawyers were creators whose works at issue were decided and shaped by judges and lawyers. The ultimate goal sought by the Great Library's copy practices was to "help ensure that legal professional in Ontario can access the materials necessary to conduct the research required to carry on the practice of law."53 This practice saves the cost of additional hotel bills and other travel expenses to non-Toronto lawyers and applies to self-represented litigants as well. ${ }^{54}$ Had the court ruled otherwise, Toronto lawyers may have received an unfair advantage over other members of the profession. Also, it has been argued that the cost of legal services would have increased for clients had the publishers been successful (lawyers would have had to pay extra for copies and would pass on the cost to its clients). ${ }^{55}$ As a result, the Supreme Court was intimately familiar with the practices and repercussions of deciding otherwise. Still, these context-specific factors are not easily applicable to other creative domains, where reaping from the copyrighted work is often the sole source of income for other kinds of creators.

\section{StATE OF JUdicial Play BEFORE CCH}

Before $\mathrm{CCH}$, the judiciary varied in its approach to fair dealing. Some courts were more restrictive and others more liberal in their reasoning.

\footnotetext{
${ }^{52}$ Updated as at 9 July 2007; see infra n 52.

${ }^{53} \mathrm{CCH}(\mathrm{n} 1)$ [63].

${ }^{54}$ Esmail (n )[28].

55 Law Society of Upper Canada "Notice to the Profession: Supreme Court of Canada Releases CCH Canadian v Law Society of Upper Canada Copyright Decision.” Though it seems that law societies were in discussion with Access Copyright nonetheless. The Copyright Committee of the Federation reaffirmed to CanCopy (now Access Copyright) its willingness to continue discussions with respect to possible blanket licenses for certain copying activities by members of the legal profession: Law Society of Saskatchewan "Copyright Notice to member of the Canadian Legal Profession form the National Copyright Committee of the Federal of Law Societies of Canada" (14 Dec 1999). $<$ http://www.lawsociety.sk.ca/newlook/News/lawsuit3.htm> (29 June 2007); access policies remain the same: <http://library.lsuc.on.ca/GL/services_access.htm>
} 
Factors like the motive of the dealing were also more pronounced, as were the policies of copyright towards non-users.

\section{RESTRICTIVE INTERPRETATION}

Most commentators argue that pre-CCH there was a restrictive interpretation of fair dealing. ${ }^{56}$ Many contend that copyright law has been quite expansionist in protecting owner's/creator's rights (here the same noted comments apply as scholarship has often conflated the two parties long before $\mathrm{CCH})$.

Perhaps most illustrative of this approach is the Michelin v CAW Canada case. ${ }^{58}$ In Michelin, the tire company sued a union for infringement for its use of the Michelin man logo (the Bibendum) in union leaflets distributed during a labour dispute.

The defendants unsuccessfully argued that the use of the Bibendum was a parody and therefore an exception to copyright infringement under fair dealing for the purposes of criticism. In placing the burden of proof squarely with the defendants, the court ruled that parody was not an exception to infringement within the CCA or within the jurisprudence. ${ }^{59}$ More pointedly, parody was not synonymous with criticism. ${ }^{60}$ The court was adamant not to rely on US caselaw where parody could exist under fair use. ${ }^{61}$ And even if the court were to have followed the US courts, fair

\footnotetext{
(2003) 16 Can JL \& Jur 217-224.

${ }^{58}$ [1997] 2 FC 306 (“Michelin”).

${ }^{59}$ ibid [60].

${ }^{60}$ ibid [61].

${ }^{61}$ ibid [63].
}

${ }^{56}$ LE Harris “Editorial” (2004) Copyright and New Media Law Newsletter.

${ }^{57}$ D’Agostino (n 3) arguing that in the context of mainstream publishing copyright law increasingly favours right holders over authors; see also CJ Craig "Locke, Labour and Limiting the Author's Right: A Warning against a Lockean Approach to Copyright Law" (2002) 28 Queen's LJ 1; A Drassinower "Taking User Rights Seriously” Ch 16 in M Geist (ed) In the Public Interest (Irwin Law Toronto 2005) 462 and S Trosow "The Illusive Search for Justificatory Theories: Copyright, Commodification and Capital" 
dealing would still have failed since the other two requirements had not been met, namely (1) the author's name or the source of the work were unmentioned and (2) there was no fair treatment. ${ }^{62}$ The court noted that exceptions should be strictly interpreted and that fair dealing in particular lists an exhaustive set of grounds. ${ }^{63}$ Accordingly, ruling otherwise would create a new exception in the statute. In this light, Michelin was extremely deferential to Parliament: "If Parliament had wanted to exempt parody as a new exception under fair dealing it would have done so.”64

This case represents a clear shunning of following a US fair use approach which was later expressly adopted in $\mathrm{CCH}$. Against $\mathrm{CCH}$, Michelin, promoting a restrictive approach, no longer seems to be good law.

\section{LIBERAL INTERPRETATION}

But before $\mathrm{CCH}$, there were also markings of a liberal interpretative approach. In Allen v Toronto Star Newspapers Ltd ${ }^{65}$ a freelance photographer sued a newspaper publisher for copyright infringement for reproducing a magazine cover which contained a photo he took on commission. While the testimony from both sides on custom of the industry resulted in divided views, the court ultimately ruled that the photographer only held copyright in the photo and not in the cover which was created by the magazine. ${ }^{66}$ The magazine did not object to reuse of its

${ }^{62}$ Pursuant to then Copyright Act s 27(2)(a.1) court remarks this requirement made pursuant to the North American Free Trade Agreement Between the Government of Canada, the Government of Mexico and the Government of the United States, 17 December 1992 Can TS 1994 No 2, 32 ILM 289 (entered into force 1 January 1994)("NAFTA") s 64(1). "The substantial quantity of the original work used in the leaflets and posters also casts doubt on the fairness of the defendant's treatment." Michelin (n 58)[70].

${ }^{63}$ Michelin (n 58) [65]; also relied on Bishop v Stevens [1990] 2 SCR 467.

${ }^{64}$ Michelin (n 58) [71].

${ }^{65}$ Allen (n 33).

${ }^{66}$ ibid. 
cover and, in any event, the court found the fair dealing defence for the purposes of news reporting applied.

The court overturned the trial decision ruling that fair dealing did not apply to an entire copyrighted work. The court held that fair dealing is "purposive" and not simply a mechanical test. In citing a US decision, "the extent of the copying is one important factor, but only one to be taken into account, along with several others." ${ }^{67}$ While the court did not schematically assess a list of factors as in $\mathrm{CCH}$, it examined the nature and purpose of the use which was found to include current news. Also, the court considered the "market substitute" criterion noted in $\mathrm{CCH}$, in that the use of the photo was "not to gain an unfair commercial advantage over [the plaintiff] Allen or [the magazine] Saturday Night." ${ }^{\text {"68 }}$ Moreover, as in $\mathrm{CCH}$, fair dealing was also allowed within a commercial context of a periodical publisher, The Toronto Star Newspaper Ltd.

As in $\mathrm{CCH}$, Allen adopted a liberal approach and weighed the following factors: (1) the purpose of relaying a current event was allowed in a commercial context (2) the nature of work as an entire work such as a photograph was fair dealing and (3) the market substitute factor allowed the court to consider that the magazine did not seek to gain a commercial advantage over the market for the original work.

Notably, regarding the extent of the work copied, in an earlier decision Zamacois, an entire newspaper article was reproduced and this was not fair dealing for purposes of criticism. ${ }^{69}$ The defendants unsuccessfully argued that, (1) the article was necessary since another article published in the same edition criticized the work and (2) the copied article was of current interest of an economic or political topic. For the court, one could not reproduce an article in full without the author's permission of the work

67 Citing Williams \& Wilkins Co v United States 417 US 907 (US Cl Ct 1974) (“Williams \& Wilkins”).

${ }^{68}$ Allen (n 33) [38].

${ }^{69}$ Zamacois v Douville (1943) 2 CPR 270 (Ex Ct)(Angers J) 302 [104] (“Zamacois”). 
which he criticizes. ${ }^{70}$ But this decision has come under much criticism and as a result of $\mathrm{CCH}$ its precedential value is weak. ${ }^{71}$

\section{MotIVE}

$\mathrm{CCH}$ did not apply motive, at least bad motive. ${ }^{72}$ In previous cases, such as in Boudreau v Lin, there was no fair dealing for private study found in a professor's paper containing substantial copied portions of a student's work. $^{73}$ The court zeroed in on the fraudulent nature of the dealing. The professor had deleted the student's name from the paper, presented it at a conference without credit and also sold copies of it to other students. ${ }^{74}$ From this perspective, even though one of the court's policy objectives was to prevent the appropriation of the author's labour, the bad faith conduct where the professor "blatantly" breached copyright seems to have weighed heavily in finding otherwise. ${ }^{75}$ It will be interesting to see the extent to which future fair dealing cases account for bad faith. By contrast in $\mathrm{CCH}$, the Great Library's closely enforced Access Policy put the defendant in a favourable light.

\section{POLICY}

While $\mathrm{CCH}$ featured a user-centric policy oriented court, previous cases were perhaps more mindful of the creator. In Breen v Hancock House

\footnotetext{
70 ibid.

71 eg some argue its weakness even before CCH: MF Morgan “Trash Talking: The Protection of Intellectual Property Rights in Computer Software” (1994) 26 Ottawa LRev arguing that Hubbard's approach seems preferable.

72 The "real purpose" or "motive” was treated as a sub-factor though not applied: CCH (n 1) $[54]$

73 Boudreau (n 33).

${ }^{74}$ ibid [49]

75 ibid [50-1] see for an interesting discussion of role of university to regulate activities of its professors especially vis-à-vis its students.
} 
Publishers Ltd ${ }^{76}$ an author copied substantial portions of a thesis into a book which he later published. In denying fair dealing, the court found that while the book enjoyed little commercial success, the defendant had appropriated the plaintiff's skill, time and talent. ${ }^{77}$ He had made liberal use of about 20 to 30 pages of the thesis which comprised a qualitative substantial portion of the author's work. ${ }^{78}$ An interesting question here is how can one argue otherwise for the "public interest" in the context of this case? Can this creator be distinguished from the authors in $\mathrm{CCH}$ who created decisions and secondary materials? It is unclear whether following $\mathrm{CCH}$, Breen would have had a similar result. Against the past, post-CCH now users stand in a better position in proving fair dealing.

\section{Post-CCH: Have CouRTS POST CCH TAKEN ITS LEAD?}

While there has been no copyright case on fair dealing post- $\mathrm{CCH}$, cases addressing copyright issues generally have considered $\mathrm{CCH}$, namely concerning the doctrine of originality, authorization, and general policy principles. $^{79}$

In the "Tariff 22" decision involving retransmission rights, the Supreme Court reaffirmed the need for a liberal interpretation in balancing rights of owners and the limitations of those rights as they are not just

\footnotetext{
${ }^{76}$ Breen v Hancock House Publishers Ltd 6 CIPR 129 (Fed Ct) (Joyal J).

77 ibid [20].

${ }^{78}$ Curiously, the infringing author had always assumed that academic work (eg like a thesis) was in the public domain and therefore not subject to copyright protection; ibid [10]

79 eg R v Allen 2006 ABPC 115 (Alb PCt) [30] on originality; Columbia Pictures Industries v Gaudreault 2006 FCA 29 (Fed CA) [32] and Columbia Pictures Industries v Frankl 2004 FC 1454 (Fed Ct) [26] on authorization. But to date no decision has applied the fair dealing doctrine. While a trial date has yet to be set, a new suit by Robertson against Thomson Corp is expected to include fair dealing; namely whether the defence of fair dealing applies to any of the infringing acts if there is no implied licence (updated as at 9 July 2007).
} 
"loopholes." ${ }^{, 0}$ Thus far the Copyright Board of Canada has in obiter made some remarks on the potential applicability of the fair dealing doctrine to licensing issues and the need for further clarification.

\section{COPYRIGHT BOARD DECISIONS}

In Re Media Monitoring, the Board considered tariffs filed by the Canadian Broadcasters Rights Agency (CBRA) for commercial and noncommercial media monitors using its private broadcasters' programs and communication signals. While the Board did not determine the extent, if any, to which the monitors' use of the repertoire may constitute fair dealing, it nonetheless commented on the potential applicability of the doctrine. It maintained that "profit-driven research may constitute fair dealing" and "that the person who facilitates another person's fair dealing may be entitled to the same protection under the Act as the first person.,"81 And that applied to this case, it could perhaps be argued "that some monitoring activity may constitute research or the facilitation of research, some of which may in turn constitute fair dealing." ${ }^{, 82}$ Accordingly,

Until subsequent judgments clarify the portent of the $\mathrm{CCH}$ decision, this leaves open the possibility that certain activities of media monitors may not constitute protected uses for which they would require a licence. ${ }^{83}$

In Re Breakthrough Films \& Television while not a fair dealing case, the dissenting opinion in the Copyright Board pronounced itself on its scope. ${ }^{84}$ The Board found that a television production company was justified to obtain a retroactive licence to work belonging to an unlocatable copyright owner it had excerpted. But for the dissent a retroactive licence should not

${ }^{80}$ Tariff 22 [88] citing CCH (n 1) [48] which had quoted D Vaver Copyright Law (Irwin Law Toronto 2000) 171: "User rights are not just loopholes."

${ }^{81}$ Re Media Monitoring (Copyright Board, March 29, 2005) [28].

${ }^{82}$ ibid [29].

${ }^{83}$ ibid [28].

${ }^{84}$ Re Breakthrough Films \& Television (Copyright Board, March 6, 2006). 
have been granted since there was no copyright infringement. In clarifying the full basis of its policy considerations, the dissent stated:

While the interests of copyright owners should be protected, so should those of users, given the recent insistence of the Supreme Court of Canada in balancing the rights of the former and those of the latter. The public interest in the dissemination of works and subject-matters also should be given some attention. ${ }^{85}$

However, fostering balance in copyright should not be at the expense of fostering compliance with copyright rules since this has a direct impact on licensing issues and ultimately on fair dealing. For the Board, "[u]sers should be encouraged to evolve towards practices where licences are sought before a work is used. The Board should not condone industry practices that view licensing copyright as an afterthought, thereby showing disregard for the rights of copyright owners." 86 In other words, proper licensing is part of the copyright balance.

While retroactive licences help foster certainty, respect for copyright and dissemination of published works, they may deprive owners from "the right to choose between agreeing to a price and seeking compensation for the violation of copyright that has already occurred.",87

And so, with respect to fair dealing the Board's work may be affected directly:

... whole areas of what are now considered to be protected uses (eg media monitoring) might suddenly join the realm of unprotected uses. This might have to be factored into the setting of certain tariffs, which brings us back to the already identified difficulties associated with applying concepts otherwise suited to an ex post facto decision in the exercise of an ex ante jurisdiction. ${ }^{88}$

\footnotetext{
85 ibid [29].

86 ibid [30].

${ }^{87}$ ibid [55] A copyright licence should not be treated as a “dog licence” ibid [56].

${ }^{88}$ Bouchard (n 33).
} 
Thus as courts and, importantly, industry practices follow the liberal interpretation of research in $\mathrm{CCH}$ to include commercial purposes this may have a direct effect on tariff-setting.

\section{Note ON THE EdUCATIONAL CONTEXT}

Even before $\mathrm{CCH}$, the Council of Ministers of Education (CMEC) proposed an educational amendment to the CCA to permit the use of freely available internet materials. ${ }^{89}$ While beyond the scope of this paper to assess this proposal, it is unclear that this provision on its own will alter the current law or practices with respect to the educational uses of materials. Although perhaps useful to generate good will among this set of particular stakeholders, for the long term, many more parties will need to come to a consensus on many more matters than the mere use of internet materials. Moreover, some scholars argue that because of $\mathrm{CCH}$, the federal government's interventions on educational use of materials for long distance learning and coursepacks, as proposed in Bill C-60, may be "at best impractical and unnecessary, and at worst unenforceable". ${ }^{90}$ As $\mathrm{CCH}$ espoused, a LAM need not rely on its specific exceptions but can rely on fair dealing. Significantly, however, fair dealing may not excuse mass distribution of materials. ${ }^{91}$ To date, these problems remain unaddressed.

The existing governance mechanisms in the educational community do not seem tenable. For example, academics, students and other critics are dissatisfied with the current licensing regime. ${ }^{92}$ Very little money flows

${ }^{89}$ see CMEC “Copyright in Education” <http://cmec.ca/copyright/copyInternet.en.stm> (last visited June 29, 2007).

${ }^{90}$ Wilkinson (n 24) 360. Bill C-60, An Act to Amend the Copyright Act, $1^{\text {st }}$ Sess $38^{\text {th }}$ Parl 2005 was introduced in the House of Commons on 20 June 2005 died on the Order of Paper on 28 November 2005.

${ }^{91}$ ibid 369.

${ }^{92} \mathrm{H}$ Knopf "Copyright Collectivity in the Canadian Academic Community: An Alternative to the Status Quo?” (1999-2000) 14 IJP 109. 
back to the professor/author. ${ }^{93}$ Consider that the then CanCopy "had more than $\$ 18$ million in undistributed royalties, and no apparently systematic way of determining to whom this money belongs." 94 These types of issues will continue to grate on students and other members of the educational community alike from teachers and librarians to the administrators of copyright. While $\mathrm{CCH}$ has liberalized greater uses of works comporting with fair dealing (eg for educational purposes), understanding and agreeing on any policy, law or court decision, must also be embraced (and perhaps generated) at the grass-roots level, by the all of the parties (in discord and accord) that are directly affected.

\section{FAIR DEALING IN THE UK}

The UK doctrine of fair dealing that has developed in the courts over almost two centuries made its first statutory appearance in the UK Copyright Act 1911. ${ }^{95}$ There has been pronounced academic debate on UK's fair dealing provision. Some scholars have argued that the UK doctrine offers no principles or vision and that it contains too many obstacles that undermine its operation. ${ }^{96}$ Yet, others maintain that UK courts adopt a liberal interpretive approach. ${ }^{97}$

Copyright, Designs and Patents Act $1988^{98}$ (“CDPA”) Chapter III of the 1988 Act, sections 28 to 76, is concerned with "Acts Permitted in Relation to Copyright Works"99 and contains the present fair dealing provisions in

93 "Few such authors are believed to earn more than $\$ 75$ to $\$ 100$ a Year from reprography royalties from CanCopy” Knopf (n 92) (CanCopy is now Access Copyright).

${ }^{94}$ ibid.

951 \& 2 Geo 5 c 46 An Act to Amend and Consolidate the Law Relating to Copyright.

${ }^{96}$ C Craig Fair Dealing and the Purposes of Copyright Protection (Queen’s University Kingston, Ontario LLM Thesis August 2000).

${ }^{97}$ L Bently and B Sherman Intellectual Property Law (2 ${ }^{\text {nd }}$ edn OUP Oxford 2004) 193.

${ }^{98}$ Copyright, Designs and Patents Act 1988 c 48 as amended (UK) (“CDPA”).

${ }^{99}$ CDPA s 31 permits certain instances of incidental inclusion of copyrighted work; ss 32 - 36 provide for permitted uses for the purposes of education; ss 37-44 contain rules regarding libraries and archives; s 45 - 50 concern public administration; ss 51-53 deal 
sections 29 to 30 which stipulate enumerated purposes similar to its Canadian counterpart: (1) research or private study (2) criticism or review and (3) reporting current events. As in Canada, at least pre- $\mathrm{CCH}$, the defendant must overcome three hurdles: (1) the dealing must fall into an enumerated category (2) the dealing must be fair (as per the common law criteria set out below) and (3) in the last two cases, there must be sufficient acknowledgment. ${ }^{100}$

Against the conclusions of previous government studies, the recent Gowers Review has not recommended that fair dealing be amended. ${ }^{101}$ Rather its recommendations follow the UK tradition to carve out specific exceptions. Gowers recommends to add several new exceptions, among which are those for parody and format-shifting. ${ }^{102}$ These two exceptions have not attracted any controversy. ${ }^{103}$

with designs; sections 54-55 deal with typefaces; s 56 is about works in electronic form; ss $57-75$ contain miscellaneous provisions; and s 76 ensures the effectiveness of defences with respect to adaptations.

${ }^{100}$ But for of current events by means of a sound recording, film, broadcast or cable programme: acknowledgement is not required: s 30(3). The purported explanation for this distinction is that on the basis that acknowledgements would unduly clutter reporting by these forms of media. A similar provision was contained in s 6(3) of the 1956 Act. Amended to give effect to Copyright and Related Rights in the Information Society 2001/29/EC art 5(3)(c) (“Information Society Directive”).

101 An independent review led by Andrew Gowers, asked by the Chancellor of the Exchequer last year December, one year target met; see An independent review led by Andrew Gowers, asked by the Chancellor of the Exchequer December 2005, one year target met; Government accepted all of the recommendations the day the Review was tabled in Parliament 6 December 2006; see <http://www.hmtreasury.gov.uk/independent_reviews/gowers_review_intellectual_property/gowersrevie w_index.cfm> Gowers goes against previous reports: The Whitford Report: Copyright and Designs Law, cmnd 6732 (1977) "The greater the number of special cases, the greater the scope for uncertainty [regarding the applicability of the fair dealing defence] in relation to cases not specifically dealt with.” [668].

102 Gowers (n 101) Recommendation 10b (format-shifting), Recommendation 12 (parody).

${ }^{103}$ United Kingdom Patent Office (UKPO) Interview (5 February 2007). 
The UK enumerated purposes are said to be liberally construed. ${ }^{104}$ By adopting an objective test, courts have made it reasonably easy to prove that a dealing fits in one of these categories. Still, this liberal construction is not consistent with $\mathrm{CCH}$ which arguably has expanded the actual allowable purposes perhaps to include a parody right in a future following of $\mathrm{CCH}$.

\section{A. What HAVE THE CoURTS SAID ON THE ENUMERATED PURPOSES?}

\section{RESEARCH OR PRIVATE STUDY}

Research and private study must be for a non-commercial purpose. ${ }^{105}$ Some UK commentators argue that a database used in market testing for a new drug or a commercial training course would constitute research or private study. ${ }^{106}$ It is still a difficult middle ground to determine what is meant by commercial. Recital 42 of the Information Society Directive mandates that one must look at the activity rather than the "organizational structure and the means of funding the establishment". ${ }^{107}$ One key factor seems to be that research need not be private. Other important factors include the amount taken, if the work is readily available, and the effect on the market. ${ }^{108}$ It is possible for an agent to photocopy works for third parties but there are limitations if the copying would result in substantial dissemination of the same material. ${ }^{109}$ Arguably, this would be the same in $\mathrm{CCH}$ which allowed copying subject to a fair dealing compliant access

104 Bently (n 97) 193; see Newspaper Licensing Agency v Marks \& Spencer plc [1999] EMRL 369 ("Marks \& Spencer”); Pro Sieben Media AG v Carlton Television Ltd [1998] FSR 43 (CA) (Walker LJ) ("Pro Sieben”) and Ashdown (n 29).

${ }^{105}$ Defined in CDPA (n 98) s 178: as not including direct or indirect commercial purpose

${ }^{106}$ Bently (n 97) 198.

${ }^{107}$ Information Society Directive (n 100).

${ }^{108}$ Bently (n 97) 198.

${ }^{109}$ CDPA (n 98) s 29(3)(b); eg instructors could not make multiple copies of articles for their students. 
policy. Still, because of $\mathrm{CCH}$, in Canada, research and private study can include commercial purposes.

In the UK, the application of this purpose has been criticized for it fails to reflect the importance of non-textual media and it applies in a limited fashion to computer programs. ${ }^{110}$ This purpose also does not apply for a broadcast, sound recording or film. ${ }^{111}$

\section{CRITICISM OR REVIEW}

For a dealing to fit this category, the subject work must have been previously available to the public, be fair and have sufficient acknowledgement. In Sillitoe and Others $\mathrm{v}$ McGraw-Hill Book Company, ${ }^{112}$ there was no fair dealing in the use of original summaries incorporated into "Coles Notes." The court found that the authors of the Notes, used very long extracts without sufficient acknowledgement. The Notes inclusion of brief commentaries under only some of the reproduced summaries was not sufficient for criticism or review. In Associated Newspapers Group Plc v News Group Ltd. ${ }^{113}$, at issue was the printing of letters owned exclusively by the Daily Mail by a competing newspaper, The Sun. The defendants' motive had not been for the purpose of criticism or review, but to "attract readers." 114 In this case, the "death of the Duchess does [did] not require the publication of the contents of the letters." 115 One could simply have reported the event.

\footnotetext{
${ }^{110}$ CDPA (n 98) s 29(4)-(4A).

${ }^{111}$ Pro Sieben (n 104).

112 [1983] FSR 545 (“Sillitoe”).

113 Associated Newspapers Group Plc v News Group Ltd [1986] RPC 515 (“Associated Newspapers”) 518.

114 ibid.

${ }^{115}$ Associated Newspapers (n 113) 519.
} 


\section{CURRENT EVENTS REPORTING}

This purpose has been generally construed as news reporting, though a recent case, Pro sieben Media AG v Carlton UK Television Ltd, has given its scope wider interpretation. ${ }^{116}$ Broadcasters have criticized Pro Sieben for its potentially wide applicability of current events now extending beyond news. ${ }^{117}$ The court has not clarified the extent of its new scope.

\section{B. The DeALING MUST BE FAIR}

Once a defendant proves that work a falls into an enumerated purpose, the defendant must show that the dealing was fair. Hubbard v Vosper ${ }^{118}$ sets out the main test for fairness. For some scholars Hubbard, "represents the first major judicial attempt to define the concept of 'fairness' with respect to the fair dealing provisions contained, at that time, in section 6 of the 1956 Copyright Act." "119 At issue was whether Hubbard's book, as the founder of the Church of Scientology of California, infringed a book authored by a former member of the Church of Scientology, Vosper, which he relied upon extensively for his own work. In denying an application for an injunction, Lord Denning for the Court of Appeal maintained that whether a dealing is fair is a matter of fact and degree and all the circumstances of a particular case must be taken into account: ${ }^{120}$

It is impossible to define what is 'fair dealing'. It must be a question of degree. You must consider first the number and extent of the quotations and extracts. Are they altogether too many and too long to be fair? Then you must consider the use made of them. If they are used as a basis for

\footnotetext{
${ }^{116}$ Pro Sieben (n 104) 625. The fact that a German television station had paid $£ 30000$ to interview a woman of multiple pregnancies was "an event of limited and ephemeral interest, but ... [still] a current event”.

117 "Verdict causes stir for broadcasters" (1999) The Lawyer 22, 22.

118 [1972] 1 All E.R. 1023 (CA) (“Hubbard”).

${ }^{119}$ Craig (n 96) 9.

${ }^{120}$ Hubbard (n 118) 1027.
} 
comment, criticism or review, that may be a fair dealing. If they are used to convey the same information as the author for a rival purpose, that may be unfair. Next you must consider the proportions. To take long extracts and attach short comments may be fair. Other considerations may come to mind also. But after all is said and done, it must be a matter of impression.",121

A court must therefore weigh the extent and proportion of the work used in relation to the original work and uses made (eg for a rival purpose). ${ }^{122}$ An entire work may also be subject to the fair dealing defence. ${ }^{123}$ Since the Human Rights Act of 1998, courts need to be flexible and considerations of public interest are paramount. ${ }^{124}$ While not expressly delineated in the legislation, from the case law, several factors emerge on what is "fair" on the most part consistent with the Canadian jurisprudence:

1. Nature of the work: if the work is unpublished, this will weigh against the defendant; ${ }^{125}$ in the case of confidential works (eg private letters) this will weigh more against fair dealing than the use of official reports of public importance.

2. How the work was obtained: if leaked or stolen it is less likely to be fair. ${ }^{126}$

3. Amount taken: while the least amount taken favours fair dealing, in some cases it may be fair to reproduce an entire work (eg if the work is short, like an epitaph). ${ }^{127}$

${ }^{121}$ ibid.

${ }^{122}$ Craig highlights that, with respect to the relevance of a "rival purpose", British Broadcasting Corp v British Satellite Broadcasting Ltd Times, [1991] 2 All E.R. 833 (Ch D), held that BSB's rivalry with the BBC did not necessarily take its actions outside the protection of the fair dealing defence.

${ }^{123}$ For Megaw LJ in the context of a parish magazine reproducing a twenty word epitaph: Hubbard (n 118) 1031.

${ }^{124}$ Ashdown (n 29) [71].

${ }^{125}$ Hyde Park (n 22) in the case of current events.

${ }^{126}$ Beloff v Pressdram Ltd [1973] 1 All ER 241 (Ch D) (“Beloff”)

${ }^{127}$ Hubbard (n 118) 94-95; 98. 
4. Uses made: the more transformative the better to favour fair dealing (eg the more that has been added by the user the better, as some have stated it pays to be long-winded). ${ }^{128}$

5. Commercial benefit: if the work is used for a commercial benefit this will weigh against the defendant; one cannot derive a commercial benefit in research, unless there is some overriding element of public advantage. ${ }^{129}$

6. Motives for the dealing: the courts employ an objective standard $^{130}$ and consider if the motive is malevolent or altruistic. ${ }^{131}$

7. Consequences of the dealing: this factor concerns the impact of the dealing on the market of the original work especially where parties are in competition; if a new work acts as a substitute for the original this weighs against fair dealing. ${ }^{132}$

8. Purpose achieved by different means: were alternatives to the dealing available? Courts have found no fair dealing when the written word was just as effective as actual pictures. ${ }^{133}$

\section{HIERARCHY OF FACTORS}

While there appears to be an open list of criteria emerging, a recent case suggests that there is a hierarchy of factors. In Ashdown $\mathrm{v}$ Telegraph Group Ltd, a UK daily newspaper unsuccessfully claimed fair dealing in its use of confidential political material it published concerning the pending formation of the UK government. ${ }^{134}$ While the case

\footnotetext{
${ }^{128}$ D Vaver Copyright Part II (Osgoode Hall Law School Toronto 1998) 522.

${ }^{129}$ Marks\& Spencer (n 104) [257].

${ }^{130}$ Hyde Park (n 125) [36].

${ }^{131}$ Pro Sieben (n 104) 614.

132 Hubbard (n 118).

133 Hyde Park (n 125).

134 Ashdown (n 29) the public interest defence and freedom of expression claim were also advanced.
} 
acknowledged Pro-Sieben's liberal interpretation of current events ${ }^{135}$ drawing from Laddie's text, ${ }^{136}$ the court delineated a hierarchy of factors when deciding fair dealing, in the following order:

(1) whether there was a market substitute to the dealing (if so, fair dealing will "most certainly fail”)

(2) whether the work was published or previously exposed to public (if not, fair dealing will fail especially if the work was obtained by breach of confidence or some other underhanded way - here motive is relevant)

(3) extent of the work taken (though a substantial part or entire work can be allowed). ${ }^{137}$

The appellate court found that the copied extract enhanced the commercial value of the newspaper, increasing its readership loyalty. And while some of the matters covered in the extract had been previously disclosed in a radio interview, the extract was obtained in breach of confidence and its most important parts were taken. ${ }^{138}$

So although the court stated that where freedom of expression is at issue, courts may need to place less weight than previously on these hierarchy of factors, and more on others such as the political importance of the contents of the work, ${ }^{139}$ copyright won out: "We do not consider it arguable that Article 10 [of the Human Rights Act] requires that the Group [The Telegraph] should be able to profit from this use of $\mathrm{Mr}$ Ashdown's copyright without paying compensation.” 140 In other words, market

135 It might impinge upon the way in which the public would vote at the next general election. The 'issues' identified by the Sunday Telegraph may not themselves be 'events', but the existence of those issues may help to demonstrate the continuing public interest in a meeting two years earlier. Ashdown (n 29) [64]

${ }^{136}$ H Laddie, P Prescott \& M Vitoria The Modern Law of Copyright and Designs $\left(3^{\text {rd }}\right.$ edn London Butterworths 200) [20.16].

${ }^{137}$ Ashdown (n 29) [70].

138 ibid [72]-[76].

139 ibid [71].

140 ibid [82]. 
impact (which is mindful of remunerating the author) may trump freedom of expression claims and appears to be the most important consideration.

Comparatively, in post-CCH Canada, market impact is not as important a factor (in the UK, it is the most important). Market impact in the UK is specifically vigilant of remunerating the author. Whether the work is unpublished may yield opposite results in Canada (unpublished works tend towards a finding of fairness, whereas in the UK unpublished works are not fair). The extent of the work taken is treated similarly in Canada and in the UK, in that it is not a factor of paramount importance. The public interest is critical in both jurisdictions, but interpreted as a user right in Canada and meant to account for human rights in the UK. 


\title{
IV. FAIR USE IN THE US
}

\author{
A. US LEGISLATION
}

Section 107 of the US Copyright Code entrenches the jurisprudence accumulated up to the 1976 revision and provides that the "fair use of a copyrighted work for purposes such as criticism, comment, news reporting, teaching (including multiple copies for classroom use), scholarship, or research" does not infringe copyright. Although the US offers an open list of permissible purposes against the Canadian and UK statutes, the caselaw has generally seen similar uses exonerated under fair use. The decision of whether a particular use is fair mandates the consideration of four statutorily entrenched factors.

\section{FOUR FAIR USE FACTORS}

a. THE PURPOSE AND CHARACTER OF THE USE, INCLUDING WHETHER SUCH USE IS OF A COMMERCIAL NATURE OR IS FOR NONPROFIT EDUCATIONAL PURPOSES

This factor considers whether the use is commercial or should be deemed transformative. More recently, good faith has been noted as a subfactor. ${ }^{141}$ Commercial use is but one factor and against a tide of caselaw is no longer presumptive. In Sony Corp of America v Universal City Studios Inc, ${ }^{142}$ a case concerning the use of the Betamax videotape recorder used for private 'time-shifting' of television programs, the court examined whether the user stood to gain from the use of copyrighted work, not whether the user had actual motive for monetary gain. In this case, time-shifting was found to be a non-commercial use. The court's obiter statement that "every commercial use of copyrighted material is

\footnotetext{
${ }^{141}$ This was not the case initially eg in Sony Corp of America v Universal City Studios Inc 464 US 417 (SCt 1984) ("Sony”) where motive was not a factor.

142 ibid.
} 
presumptively unfair" ${ }^{143}$ was later embraced by subsequent courts seeking a bright-line to interpret fair use cases, but was ultimately rejected in Campbell v Acuff-Rose Music Inc. ${ }^{144}$

Acuff-Rose, also known as the "Pretty Woman" case, concerned the parodic use of Roy Orbinson's song by rap group 2 Live Crew. Overruling the lower court, the appellate court relied on the Sony presumption and found that fair use did not exonerate the rap group. However, the Supreme Court later overturned this decision stating that the commercial nature of a work should not be dispositive. Rather, "parody, like any other relevant use, has to work its way through the relevant factors and be judged case by case, in light of the ends of copyright law." ${ }^{145}$ Relying on such a presumption would have distorted fair use and would have been "suggestive of a [US] judicial tendency to establish bright-line rules, evolved from in-built biases or assumptions... ${ }^{146}$ Today, in the US, there is no presumption against fair use if the defendant makes a commercial use. Commercial uses tend to weigh in favour of the plaintiff. ${ }^{147} \mathrm{CCH}$ thus goes beyond US fair use, as the commercial nature can be one consideration and must not be one factor always considered.

In Rogers v Koons, ${ }^{148}$ Koons a successful artist sculpted a "String of Puppies" to parody the plaintiff's photograph of eight "Puppies” which had enjoyed wide commercial success. In doing so, he also used an enlarged photocopy of the puppies. The court rejected the parody argument, as Koons could have expressed the parody without directly copying Rogers' work. Koons' work was not commenting directly on the

\footnotetext{
143 ibid 451.

144510 US 569 (SCt 1994) (“Acuff-Rose”).

${ }^{145}$ Harper \& Row (n 26) 1172.

${ }^{146}$ Craig (n 96) 128.

${ }^{147}$ ibid 125. This was the real intention of the court to set up a "balancing of the fair use factors".

${ }^{148}$ Rogers v Koons 960 F 2d 301 (2d Cir 1992).
} 
work itself, but rather on a general idea, so there was no need to copy. Also the court found bad faith and copying for profit-making motives. ${ }^{149}$

Basic Books v Kinko Press, is the US “coursepacks” case where uses of copyrighted material for educational purposes by a commercial enterprise were not fair use. The four factors were analyzed. The copying was non transformative and was on a commercial scale. ${ }^{150}$ While it was unclear how much profit Kinko made, the court found it important that Kinko had the intention of making profits. ${ }^{151}$ And so, its motives were only "purportedly altruistic."152 This case can be contrasted with Williams \& Wilkins where a government department copied articles from medical journals and disseminated them to researchers and personnel who requested them. The court found that the purposes of study and research were acceptable as these were socially useful objectives and not "true to photocopy shops, which reproduce for profit." 153 Further, the libraries had established fair use guidelines and did not charge a fee.

A court post-CCH could yield similar holdings: accounting for parody and educational uses of works by government departments. In the UK, however, parody would still be prohibited.

\section{b. THE NATURE OF THE COPYRIGHTED WORK}

For this factor courts consider whether the work is factional or fictional and whether published or unpublished. If there is substantial creativity, this tends to favour the owner.

\footnotetext{
149 ibid 310.

150 "The effort utilized in this case was questionable at best and the level of judgment practically non-existent.” 758 F Supp 1522 (NY Dt 1991) (“Kinko”) 1529.

151 ibid.

152 ibid. "The insistence that theirs [motives] are educational concerns and not profitmaking ones boggles the mind.”

153 cited in Kinko (n 150)1535; this can be contrasted with American Geophysical Union v Texaco 37 F3d 882 (2d Cir 1994): a class action by 82 scientific publishers against Texaco for copying its works to which it subscribed without paying royalties.
} 
With respect to unpublished works, Harper \& Row Publishers, Inc v Nation Enterprises ${ }^{154}$ seemed to have instilled a presumption against fair use for unpublished works which was followed by lower courts. But Congress responded to the publishing industry's concerns and overruled this presumption. ${ }^{155}$ In this case, a magazine (the Nation) published unauthorized quotations from former US president Ford's unpublished memoirs. The court analyzed the four factors and denied fair dealing. Specifically, the court reasoned that the author has the right to control the first appearance of the work, as part of the right of first publication which encompasses the choice of whether to publish at all, when, where and in what form. ${ }^{156}$ In this case, the court found that Ford's memoirs were subject to a confidentiality agreement and that any article produced from it would need approval. Further, the Nation's “clandestine” publication afforded no opportunity for the author's "creative or quality control" and contained a number of "inaccuracies". 157 The court found that the unauthorized quotations focused on "the most expressive elements of the work, [which] exceeds that necessary to disseminate facts."158 In Basic Books while the court did not find fair dealing it noted that because the nature of the works was for educational purposes this factor weighed in their favour. ${ }^{159}$ The US and UK seem consistent in their interpretation of this factor, against the Canadian approach favouring users disseminating unpublished works.

C. THE AMOUNT AND SUBSTANTIALITY OF THE PORTION USED IN RELATION TO THE COPYRIGHTED WORK AS A WHOLE.

This factor leads to a sliding scale: as the dealing goes above a de minimis use it more likely goes against fair use. Courts still focus on what and not how much is used-the quality over the quantity of the taking is

\footnotetext{
${ }^{154}$ Harper \& Row (n 26) 546.

${ }^{155}$ Fair Use of Unpublished Works Publ No 102-492 (1992) 102d Cong 2d Sess., 106 Sat 3145 codified at 17 USC 107.

${ }^{156}$ Harper \& Row (n 26) 562.

157 ibid.

158 ibid.

${ }^{159}$ Kinko (n 26) 1533.
} 
critical. In Basic Books entire chapters were copied and meant to stand alone therefore both quantitively and qualitatively significant. In Harper \& Row the court focused on quantity and quality: though insubstantial, the extracts were the "heart of the book." 160 In Acuff-Rose, 2 Live Crew departed from the 'heart' and produced distinctive lyrics. Though when weighed with the character of use, entire works may be fair use. On the whole, as in Canada and the UK this factor seems like the least significant.

\section{d. THE EFFECT OF THE USE UPON THE POTENTIAL MARKET FOR OR VALUE OF THE COPYRIGHTED WORK.}

Harper \& Row signaled this last factor as the single most important factor especially if the use becomes widespread and undermines the author's potential market (since for the court the purpose of copyright is also to provide incentive to authors). ${ }^{161}$ Some lower courts have followed this dictum. ${ }^{162}$ Still, it is difficult for courts to anticipate the curtailment of the potential market as it can be like gazing in a crystal ball. ${ }^{163}$

In Basic Books the purchase of the coursepacks was found to undermine the need to purchase full texts. The court also held that this would impact out-of-print books whose licence fees constituted a significant source of

\footnotetext{
${ }^{160}$ Harper \& Row (n 26) 565. In the case of parody, Harper \& Row found this factor not very helpful because the parody necessarily must "go to the original's 'heart' since the 'heart' is what conjured up the song for parody; ibid 586-89; eg first line of lyrics and characteristic opening bass riff.

161 "More important, to negate fair use one need only show that if the challenged use 'should become widespread, it would adversely affect the potential market for the copyrighted work.' Harper\& Row (n 26) 567 following Sony (n 141) 451 [emphasis in original]; isolated instances of infringements "become in the aggregate a major inroad on copyright that must be prevented.” Harper \& Row (n 26) 567

162 eg Arica Inst Inv v Palmer 970 F2d 1067 ( $2^{\text {nd }}$ Cir 1992) 1078; Los Angeles News Serv v Tullo, 973 F 2d 791 at 798 ( $9^{\text {th }}$ Cir 1992); Cable/Home Communication Corp v Network Prods Inc 902 F.2d 829 at 845 (11 ${ }^{\text {th }}$ Cir 1990).

163 Nunez v Caribbean Intern News Corp 235 F3d 18 ( $1^{\text {st }}$ Cir 2000) on market of photographs. Though it is clear that bootlegged CDs or software unfair. US v Slater 348 F3d 666, 669 (where there was no abuse of discretion in refusing to instruct on fair use in criminal trial concerning unauthorized distribution of software).
} 
income. ${ }^{164}$ Generally, in parody it is difficult that the work will act as a market substitute, as parody and the original serve different market functions. ${ }^{165}$ But in Rogers $v$ Koons there was a presumption that the sculpture would harm the plaintiff's future market. ${ }^{166}$ And on an earlier motion for summary judgment in Acuff-Rose, the absence of evidence on the effect of the parody on the nonparody market (eg Orbison's market) caused the defendant to lose. ${ }^{167}$ In the US, market substitute is therefore a very important factor, in the UK, the most important and in Canada not as important and when considered $\mathrm{CCH}$ appears to place the onus of proof on the plaintiffs.

Irrespective of the US's statutory entrenchment of the four factors, it is still very difficult to determine a fair dealing and assess which if any factor is determinative.

In other words, each of the four US statutory criteria require mandatory consideration in every case. As Acuff-Rose held there are no bright lines, few presumptions, and there must be a sensitive balancing of interests. Some argue that these criteria may enhance predictability but have reduced the flexibility available to the US court; others maintain that there is no predictability, it is difficult to articulate what fair use is, but that there is flexibility with emerging technologies. ${ }^{168}$ Ultimately, not all factors have to be fair for the end use to be fair and similarly, some factors can be fair but the end result is an unfair use.

\footnotetext{
${ }^{164}$ Kinko (n 150) 1534.

165 Relying on Sony (n ) 451; Harper \& Row (n 26) 590-594.

${ }^{166}$ Rogers (n 148) 312. An example is raised on a movie adaptation of a book impacting the potential market of selling the book's adaptation rights.

${ }^{167}$ Harper \& Row (n 148) 590-594.

168 eg C Correa "Fair Use in the Digital Era" (Unesco Paris 2000). http://webworld.unesco.org/infoethics2000/documents/paper_correa.rtf (29 June 2007)
} 


\section{2. “OTHER” FAIR USE FACTORS}

In the recent case of Basic Books, the court considered other factors, besides the enumerated four factors:

\section{a. MONOPOLISTIC AND COMPETITIVE PRACTICES}

In Basic Books, the defendant Kinko created a new "nationwide business" allied to the publishing industry by usurping the plaintiff's copyrights and profits. ${ }^{169}$ Kinko had two hundred stores across the country and it was difficult for the plaintiff to challenge the defendant. Kinko asserted that the plaintiffs misused their copyrights and monopolized the industry in an effort to thwart the copying market and restrain competition. ${ }^{170}$ While Kinko advanced anecdotal evidence that there were unreasonable delays, undue response times and high costs in obtaining copyrighted materials for the courses, the court found no clear evidence. Importantly, the court implied that had there been such evidence, then this would have weighed in favour of fair use. The court seems to leave this door open for future cases. That is, fair dealing may be found if the defendant is able to show that the plaintiff engaged in monopolistic practices. In $\mathrm{CCH}$, this factor was considered though the plaintiff had the burden of proof and failed to meet it.

\section{b. INDUSTRY PRACTICES AND INSTITUTIONAL POLICIES}

In Basic Books, the court noted that the defendant had violated "Classroom Guidelines" prohibiting the use of anthologies. Moreover, the court observed that the defendant had not advanced evidence that an instructor would be disabled without the use of the coursepacks. The court considered Williams \& Wilkins where the library copying was subject to guidelines within fair use and did not charge a fee. ${ }^{171}$ Following institutional guidelines within fair dealing is also very important in $\mathrm{CCH}$ as the court relied heavily on the Great Library's Access Policy for a finding of fairness. So, if the defendant can show adherence to policies

\footnotetext{
${ }^{169}$ Kinko (n 150) 1534.

${ }^{170}$ ibid. 1538.

${ }^{171}$ ibid. 1535 citing Williams \& Wilkins (n 67).
} 
within fair dealing/fair use this factor will likely weigh strongly in their favour.

\section{FAIR USE IS “ILL”}

Before proceeding to outline some comparative threads among the three jurisdictions, some remarks must be made on the burgeoning body of scholarship, studies and reports criticizing US fair use. Fair use is said to be "ill, though hardly dead yet." "172 Peter Jaszi argues that claims of US fair use superiority are often misguided and many others have called on Congress to clarify fair use. ${ }^{173}$ There has been no shortage of solutions proposed. ${ }^{174}$ But to date Congress has resisted changing fair use. The courts have also failed to simplify fair use by attempting to establish bright-line presumptions (1) that commercial uses are unfair, ${ }^{175}$ (2) favouring plaintiff's unpublished works, ${ }^{176}$ and (3) more recently, that works must be transformative to constitute fair use. ${ }^{177}$ Moreover, it is increasingly expensive to mount litigation to clarify the scope of use and some users may be risk-averse to begin with. The American Intellectual Property Law Association estimates the average cost to defend a copyright case to be just under one million US dollars. ${ }^{178}$

${ }^{172}$ W Gordon “Keynote Fair Use: Threat or Threatened” (2004-2005) 55 Case W Reserve LRev 912 arguing that overbroad contract rules and the DMCA are the true threats to fair use.

${ }^{173}$ P Jaszi "Public Interest Exceptions in Copyright” [copy with author]; MW Carroll "Fixing Fair Use" "Fixing Fair Use". North Carolina Law Review, Vol. 85, 2007 available at SSRN: <http://ssrn.com/abstract=945194> 4.

174 Jessica Litman proposing an unfair competition standard for infringement; Michael Madison thinks that fair use should be re-written with more flexibility so that social practices that can benefit from fair use inform the analysis. See Carroll (n 173) 11 for about a half page footnote detailing all of these sources.

${ }^{175}$ Presumption arose in Sony (n 141).

176 Congress amendment: "The fact that a work is unpublished shall not itself bar a finding of fair use” 17 USC s 107 (2000) see discussion in Gordon (n 172) 910.

177 Acuff-Rose (n 144) seconded Sony’s rejection, along with recent cases such as Nunez (n 163) exonerating nontransformative or exact copies of works.

${ }^{178}$ Cited in White Paper (n 24) 57. 
Although fair use's attention to context is certainly salutary, "it is so casespecific that it offers precious little to artists, educators, journalists, Internet speakers, other" who want to use the copyrighted work. ${ }^{179}$ Google's digitization project of large library collections is a recent sign that in the digital age, issues of fair use have taken on urgency. ${ }^{180}$

The Chilling Effects Report documents the culture of anxiety that now exists as rights holders aggressively attempt to thwart potential fair uses of works. $^{181}$ Via private cease-and-desist letters, online service providers frequently cull user materials in order to earn a place in the "safe harbour" zone. ${ }^{182}$ And because the material is removed privately, no court examines the validity in advance of takedown. Further, a recent report from the Brennan Centre for Justice, "Will Fair Use Survive?” identifies in addition to cease-and-desist letters, notice and takedown, narrow industry "fair use guidelines" and an overzealous "clearance culture." ${ }^{183}$ And more recently, the "Digital Learning Challenge" White Paper focuses specifically on the educational sector, calling for clearer fair use rules. The study reveals that the trend is for educators to clear for fear and license unnecessarily multiple copies of works for classroom use (typically allowed by statute). ${ }^{184}$ Doing so out of excessive caution, when fair use would

${ }^{179}$ D Nimmer "Fairest of them All' and other Fairy Tales of Fair Use” (2003) 66 Law \& Contemp Probs 263, 280 "had Congress legislated a dartboard rather than the four fair use factors... it appears that the upshot would be the same.”

${ }^{180}$ In Author's Guild et al v Google (filed September 20, 2005 in NY DCt) Google is arguing fair use in defence.

${ }^{181}$ Chilling Effects (n 24) eg merely providing a link to content on another website.

182 s 512 of the Digital Millennium Copyright Act ("DMCA”) Pub L No 105-304, 112 Stat 2860 (Oct 28, 1998) provides “safe harbour” from copyright infringement.

${ }^{183}$ M Heins and T Beckles “Will Fair Use Survive?” New York Brennan Center for Justice 2005 <http://www.fepproject.org/policyreports/WillFairUseSurvive.pdf>

${ }^{184}$ White Paper (n 24) 57 documenting: “Comment of the University of Texas System, <http://www.copyright.gov/disted/comments/init020.pdf> at 5 indicating that the University seeks licenses for all copyrighted material, for lack of confidence in protections provided by fair use; but see Comment of the University of North Carolina at Chapel Hill provided in White Paper (n 24) indicating that the university encourages professors to take advantage of the fair use doctrine for one-time or first uses of copyrighted material. 
otherwise apply, is harmful. ${ }^{185}$ There is also extensively documented evidence of burdensome and uneven licensing systems and arrangements within schools. ${ }^{186}$

What is more, there is a clear and negative interface between digital rights management (DRM) technologies and fair use. ${ }^{187}$ For instance, smaller schools (such as elementary and secondary schools) in the US lacking resources (and potentially skills) are precluded from licensing works if they do not comply with DRM requirements imposed by rights holders to begin with. ${ }^{188}$ The implications are that there is less use of content otherwise available and if available, prohibited from access because of the lack of resources. And while educators are generally averse to technological protection measures, they may use them nonetheless to ensure the integrity of their works and attribution of their efforts, and enforcement of how their works may be used. Also, educational institutions themselves, concerned with a return on investment, endorse DRM systems. ${ }^{189}$ As such, rights holders are not the only parties responsible for limiting access to digital works. ${ }^{190}$

The White Paper concludes that the judicial interpretation of the DMCA's anti-circumvention and anti-trafficking provisions to exclude fair use and other copyright exemptions as defences to actions under the DMCA "stripped educational users of their shield against copyright infringement liability..."191

\footnotetext{
${ }^{185}$ White Paper (n 24) 58.

186 ibid 60-63.

${ }^{187}$ Much scholarship exists eg S Blythe “The US Digital Millennium Copyright Act and the EU Copyright Directive: Comparative Impact on Fair Use” (2006) 8 Tul JTech and Intell Prop 111, 129.

${ }^{188}$ White Paper (n 24) 52.

189 ibid. 54.

190 Here it is noteworthy that a Creative Commons type licence is used increasingly to achieve these means.

${ }^{191}$ White Paper (n 24) s 4.2.4. on Educational Impact.
} 


\section{LIMITS OF TEACH ACT}

The Technology, Education and Copyright Harmonization Act of 2001 ("TEACH Act”) which promised to update educational use exemptions in light of technological developments has not delivered. ${ }^{192}$ The TEACH Act was the product of compromise among the stakeholder community and the result of a full study Congress conducted in $1998 .{ }^{193}$ The TEACH Act: (1) expanded the types of content that could be used (2) allowed the digitization and short-term retention of content, and (3) eliminated a provision in the US copyright legislation that required students to be physically on location.

Nonetheless, many strictures make the Act unworkable and unreliable and ultimately of little value. While it deals with online learning, it is very specific on what may be used without first obtaining permission. ${ }^{194}$ An educational institution must also be not for profit and accredited.

As the White Paper notes, the user must use technological protection measures (which often necessitate financial resources) and the actual use of technological protection measures "may eviscerate the TEACH Act all together." ${ }^{195}$ The TEACH ACT "failed to create a safe harbor it promised, effectively leaving educations users of digital content without legal recourse to make use of such works." ${ }^{, 196}$ The White Paper recommends to revise the TEACH ACT. ${ }^{197}$

\footnotetext{
${ }^{192}$ H.R. Rep. No. 94-1476.

${ }^{193}$ Berkman Center for Internet and Society at Harvard Law School "Digital Learning and Legal Background Paper: The TEACH ACT-The Impact of Copyright and Compromise on Digital Distance Education” at $<$ http://cyber.law.harvard.edu/home/dl_teachact> (18 June 2007).

194 R Fry “Copyright Issues in E-learning” (2004) 3:2 Copyright and New Media Newsletter. See also <http://www.lib.ncsu.edu/scc/legislative/teachkit/> (19 June 2007)

${ }^{195}$ White Paper (n 24) 34.

196 ibid. 54.

197 ibid. 71.
} 
And so, as it is not meant to alter fair use, fair use seems to be the preferred vehicle of choice in the distance learning environment. ${ }^{198}$ Though as explored fair use comes with its own uncertainties.

\section{REASONS FOR OPTIMISM: BEST PRACTICES}

The White Paper notes some grounds for optimism as (1) it views "educational uses" under the fair use doctrine to be likely permissible, and (2) there are virtually no decisions that apply fair use directly to educational defendants who made educational use of their contents. The only cases are those of commercial "coursepack" publishers, but not of the teachers making nonprofit educational uses of content. ${ }^{199}$ A high profile case where New York University was the defendant was settled in 1983 before any decision was reached. ${ }^{200}$ The White Paper posits that this neartotal absence of lawsuits against educators, "may suggest that rights holders have tacitly accepted that the appropriate construction of the fair use doctrine leaves significant room for educational uses of content, or that they fear a negative public reaction if they sue educators." ${ }^{201}$ Indeed, some universities encourage that professors rely on the fair use doctrine for one-time or first uses of copyrighted material. ${ }^{202}$ But the cases of comfort are limited, and the vast majority of users (from teachers, librarians, lawyers and educational administrators) face fear and anxiety over acceptable uses of content. ${ }^{203}$

Some of these stakeholders are trying to clarify the scope of fair use through self-help. ${ }^{204}$ Particularly, stakeholders have come together to

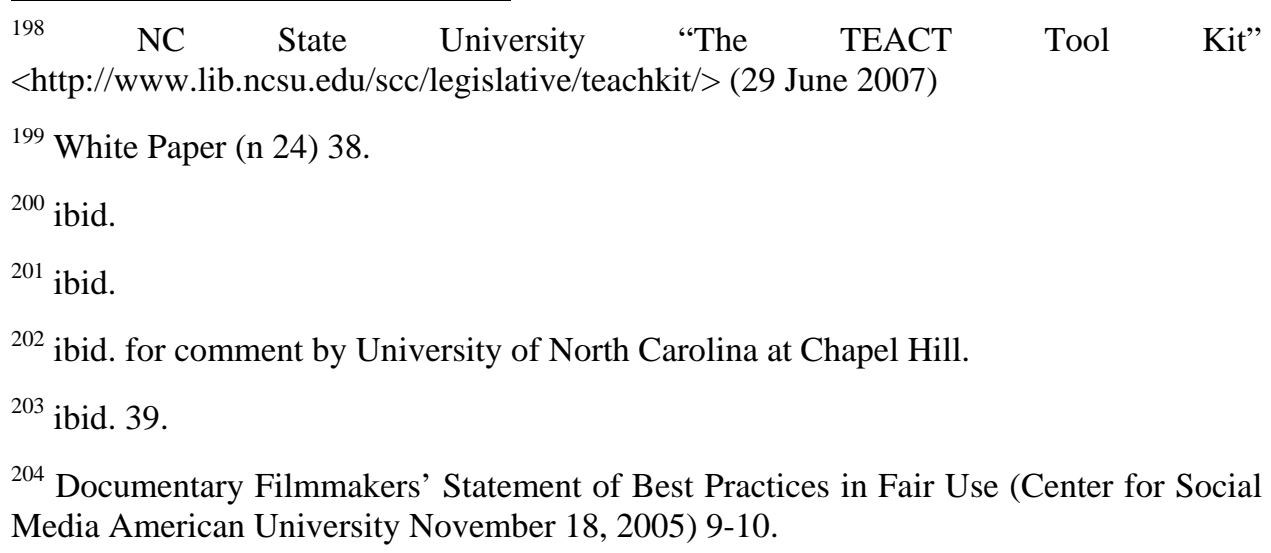


establish best practices at the university and industry-specific levels. The most successful and comprehensive initiative is a recent one from the documentary film-makers' industry. ${ }^{205}$ Diverse stakeholders from the creators to the producers to the insurers have come together and developed a statement on "Best Practices in Fair Use." This 2005 document has been well-received and there is evidence that other industries are following suit. $^{206}$ These initiatives are most promising since clarification, understanding and respect for copyright use, creation and dissemination will best occur at the grass-roots level. Parties directly involved in the industry and therefore presumably more knowledgeable can formulate best practices. As in the film-makers' case, the insurers who will have been involved in this consensus-building can then confidently "sign off" and generate more possibilities for a greater variety of works for the public. These best practices can be thus applied by the creators to insurers of copyright and, eventually, as interpretive aids by the judges in the courts in the benefit of the public at large.

In the US, attempts to agree on industry-wide guidelines for fair use have failed. The most prominent example was the Commission on Fair Use (CONFU) which met regularly throughout the 1990s. ${ }^{207}$ This ambitious attempt at a blanket approach indicates that more tailor-made culturalspecific solutions are necessary and attainable for fair use of copyrighted works.

\section{Comparative Assessment}

While Canada and the UK appear to have a more rigid "fair dealing" framework, and the US a more flexible structure, the results of what has been generally considered fair dealing/fair use have been on the most part

\footnotetext{
205 ibid.

206 Harvard Internet \& Society Conference "Knowledge Beyond Authority" (Harvard University June 1 2007) <http://www.is2k7.org/working-groups>

${ }^{207}$ Internationally, the International Federation of Libraries Associations has also looked at issue; see generally http://www.ifla.org/ (29 June 2007).
} 
similar. ${ }^{208}$ David Vaver argues that even before CCH, Canadian courts applied similar criteria, the only difference was that fair use may have applied to any situation, not merely one enumerated. ${ }^{209}$ Today, unlike the UK, Canada's enumerated grounds are no longer rigid. $\mathrm{CCH}$ has expanded Canada's purposes since these should not be given restrictive interpretation. With respect to the criteria, while the US has a statutorily entrenched four-factor approach (but with some other factors that have been considered, eg monopolistic practices, industry custom) $\mathrm{CCH}$ has considered six factors with these more or less serving as a future guiding framework. It is expected that other unnamed factors may be considered in future cases. In other words, the Canadian factors can now be seen as more flexible than those in the US. For the UK, criteria has emerged from the caselaw consonant to Canada's pre-CCH framework, and in many ways there is now a hierarchy.

\section{A. Hierarchy OF FACTORS, Not NumBer OF FACTORS}

The jurisdictional differences are apparent in the type of factors given more weight, and not entirely in the number of factors named. Or put differently, examining the hierarchy of factors, as existent in the UK, reveals the courts' approach. A useful exercise is to revisit the $\mathrm{CCH}$ factors compared to those considered in the US and UK.

While the character, amount, effect and alternatives of the dealing ( $\mathrm{CCH}$ factors $2,3,4,6)$ are similar in each jurisdiction, the purpose and nature of the work (CCH factors 1 and 5) contain some differences.

\section{PuRPose (AND COMMERCIAL NATURE OF THE DEALING)}

\footnotetext{
${ }^{208}$ Eg fair dealing/fair use was used exonerate newspapers for using third party photographs to illustrate a news story: Allen (n 33) and Nunez (n 163) but course-book compilers have been liable for reproducing journal articles and book chapters: Boudreau (n 33); Princeton University Press v Michigan Document Services 99 F3d 1381 (6 ${ }^{\text {th }}$ Cir 1996).

${ }^{209}$ Vaver (n 6) 150.
} 
The purpose of the dealing (and its commercial nature) is the factor that seems to be most undermined in $\mathrm{CCH}$, yet most pronounced in the UK (as being on the top of the hierarchy, indeed commercial is only allowed in review and criticism) and one of four significant factors in the US.

\section{NATURE OF THE WORK}

Each jurisdiction considers this factor, except that $\mathrm{CCH}$ has now curiously pronounced the opposite holding: if a work is unpublished it weighs in favour of fair dealing. In the UK and the US, if a work is unpublished it weighs against fair dealing. This interpretation reveals in particular the court's penchant to favour users.

The role of other factors that were considered pre-CCH in Canada, and are currently key factors in the US and UK, is questionable. For instance, the role of bad faith was not present in $\mathrm{CCH}$, arguably as there was none. Still this was not highlighted expressly as a potential factor. This silence does not mean that it cannot feature in future cases - as the factors were more or less six.

\section{B. OTHER FACTORS}

The real differences lie in the policy preoccupations held by the respective courts. In Canada, it is clear that the shift is one championing the rights of users to "balance" copyright. Though as noted, it is not at all clear where the creators fit in this schema, and further, creators are repeatedly conflated with right holders. This could not be further from the realities of copyright practices. Perhaps in the UK since commercial exploitation is at the fore of judicial concern one can argue that right holder interests are paramount. In the US, the pendulum swings back and forth among the various stakeholders. At bottom, it is difficult to regulate these policy preoccupations with certainty. The most effective regulator may be the public climate (as has been the case in Canada in advancing user rights) and corresponding best practices that need to be articulated. 


\section{CONCLUSIONS}

An obvious question at this late stage is to ask whether Canada's fair dealing is ill? While perhaps not ill, fair dealing in Canada may have the common cold or, may have been ill and is now in convalescence. So while surgery may not be necessary some attention may be due. Potential remedies become apparent and (in the spirit of $\mathrm{CCH}$ ) there may be others that are worth considering, not noted below.

\section{A. DO NOTHING?}

Doing nothing would involve waiting to see other cases apply CCH and industry and the Canadian general public muddling about trying to find their own way through allowable uses. Sanctioning this copyright convalescence does not seem to be an appropriate response. Indeed, legislative initiatives for other copyright matters are presently under serious consideration (eg technological protection measures which may affect fair dealing). Arguably, these initiatives will make copyright more expansionist than it already is. Further, there remains a high degree of uncertainty in the varying copyright sectors, such as the educational sector. In the US, the uncertainty in the educational fair use has very recently led to the Copyright Clearance Center offering blanket licences for academic institutions. ${ }^{210}$ However, there are strong arguments to suggest that this may not be the way forward. ${ }^{211}$

\section{B. LEGISLATE CCH FACTORS?}

\footnotetext{
${ }^{210}$ Copyright Clearance Center "Copyright Clearance Center Announces Annual Copyright License for Academia” $<$ http://www.copyright.com/ccc/viewPage.do?pageCode=au143> (22 June 2007).

${ }^{211}$ eg such licences could undermine the very purpose of fair use by requiring licensing for materials already freely available under statute. Poor institutions may also be disadvantaged: J Boyle “The Inefficiencies of Freedom” Financial Times (1 July 2007) $<$ http://www.ft.com/cms/s/25cf260c-265c-11dc-8e18-000b5df10621.html>
} 
It has been suggested that government intervene and legislate the $\mathrm{CCH}$ factors. It is not clear how this would be done since the court was clear that there are more or less six. More importantly, why would this be done? What Canada now has is a flexible framework to evaluate fair dealing on a case by case basis based on the ethos that users have rights. This seems fairly clear and will be applied and adapted to future cases, in the common law way. The fair dealing enumerated purposes can be interpreted in the same fashion. $\mathrm{CCH}$ has set a strong precedent and unless Parliament disagrees with any of its pronouncements it seems inopportune to intervene at this time. Legislating CCH may invite even more confusion.

\section{CHERRY-PICK OTHER LAWS?}

Some commentators have championed that Canada adopt US fair use. This would entail "cherry-picking" from the US cadre of copyright laws and taking from it its fair use provision. There are problems with this approach. First, as noted from eminent US studies, fair use is "ill" and not the panacea approach that many, perhaps in Canada, proclaim. Because fair use is ill, it has by necessity engendered many fix-it approaches, some by the courts themselves attempting to impose bright-lines (eg presumptions on commercial uses) and by industry players attempting to institute best practices. Second, cherry-picking a law, likely also means taking from its jurisprudence (and neglecting other constitutive factors, such as a Constitution). Would Canadian courts apply US fair use cases? Would this application ignore the fact that property is not constitutionally entrenched in Canada? Singapore has cherry-picked US fair use, however its courts are reluctant to consider US fair use cases causing much disorder. This approach would cause more perplexity than currently exists. One must be very careful when importing legal devices from other jurisdictions.

In this context, it is also useful to consider whether fair dealing necessitates clarification to encompass important (and new) uses. In the UK, Gowers recommended that the government should enact a new copyright exception for parody. Before CCH many scholars posited that parodies would be infringing in Canada. Post CCH's liberal interpretation of the enumerated grounds, it could be argued that "criticism" could now 
encompass parody. Michelin no longer seems good law. Indeed, parody in the US is not an automatic. Parody still requires analysis of each of the four factors as well as some use of the target to be fair. ${ }^{212}$ This can now also be the case in Canada and would likely not require any legislative intervention.

Similarly, time-shifting that comports with fair dealing criteria could now be allowed in Canada, as it has long been in the US. In the UK, Gowers is again recommending a copyright exception but for format-shifting. With respect to Crown copyright, $\mathrm{CCH}$ clarifies that the copying of judicial decisions is permissible and it is likely that other government works used in a similar fashion would also be. ${ }^{213}$ Still, in Canada because of Crown copyright more work is subject to protection, which is not the case in the US but very much the reality in the UK and there are no plans in that country to address this. This issue may require more consideration.

In the ambit of the educational sector, while questionable as to whether specific provisions, even amending fair dealing (such as adding 'educational uses' as an enumerated ground), are useful or even necessary, it does seem apparent that clarification (and not necessarily of the legal type) is critical across the various sectors. One disadvantage of introducing a new law is that it may take time before the quick fix that is sought is achieved and may never be achieved. New practices will develop to likely test the limits of the new law through more court cases, thereby inviting access to justice issues for the more disadvantaged parties. And so, if clarity is the goal it is unclear that it can be attained in the immediate future in this way.

\section{FAIR DEALING BEST PRACTICES?}

Rather than (or at least complimentary to) reforming the law, fair dealing best practices are most promising. The parties directly affected in a

${ }^{212}$ Dr Seuss Enterprises LP v Penguin Books USA 109 F3d 1394 ( $9^{\text {th }}$ Cir 1997) upheld a preliminary injunction, ruling against fair use. see also Carroll (n 173) 28.

213 Though CCH, suggests that photocopying the decision itself are not subject to copyright, decisions with headnotes, summaries are. 
specific industry can together develop these guidelines which can ultimately aid in fair dealing decision-making in the courts. There have already been successful guidelines or best practices generated in the US where stakeholders with apparent disparate interests in the documentary film-making sector have devised fair use best practices. The interest is also apparent internationally and locally, though from a common set of stakeholder interests (eg within universities and libraries in both Canada and the US). In Canada, most educational institutions have devised copyright policies to deal with the use of copyrighted materials by its patrons. The Great Library of Toronto continues to have one. ${ }^{214}$ Osgoode Hall Law School and York University have developed a policy. ${ }^{215}$ Concordia University has a policy (which appends the Copyright Act) and has also struck working groups to study these issues. ${ }^{216}$ Indeed, libraries continue to play an important role in the negotiation, implementation, and managing of licences. Staff are asked to regularly enforce and interpret copyright issues for compliance. ${ }^{217}$ These are promising starts, but more concerted industry efforts as spearheaded by the US documentary filmmakers can and should be emulated.

More parties with conflicting interests within a set sector need to come together. As noted, this can clarify fair dealing uses for all from the creators, users, right holders to the courts, who can then rely on these standards as "soft law" when interpreting fair dealing cases. These initiatives can and should be encouraged to flourish and will at worst, help foster communication and dialogue among different parties. But the benefits can be far more reaching and consequential to future fair dealing (and general) copyright practices. $\mathrm{CCH}$ favours parties that abide by their

\footnotetext{
214 Great Library, LSUC “Access to the Law Policy and Guidelines" <http://library.lsuc.on.ca/GL/services_access.htm> (29 June 2007)

215 York University "Copyright" <http://www.yorku.ca/secretariat/senate/committees/lit/copyright/Copyright\%20and\%20 You.pdf> (29 June 2007)

216 Concordia University "Policy on Copyright Compliance" (February 28, 2001) <http://web2.concordia.ca/Legal_Counsel/policies/english/SG/SG-2.html> (19 June 2007)

${ }^{217}$ see LE Harris “Editorial” (2004) 8(3) Copyright and New Media Law Newsletter .
} 
institutional access policies, their case could be more persuasive if such policies were consistent across their industry. Such context specific guidelines should be developed to ensure that all parties are compliant with copyright and in healthy agreement.

\section{E. CLARIFY COPYRIGHT ACT? CLARIFY POLICY OBJECTIVES?}

Just as one cannot cherry-pick laws from other countries, it is difficult to cherry-pick problems and solve problems within the Canadian copyright system. Fair dealing cannot be addressed in a vacuum. One must revisit the entire CCA and study what its objectives are, where the balance is being struck. Are right holders the so-called winning parties? Whose interests is copyright law meant to serve?

As noted in various parts of this paper, the question remains where is the author/creator? CCH does not appear to account for her. The Copyright Board has also flagged this oversight. In the current Canadian judiciary, public and academic copyright climate, creators' "rights", if one can still use the two words together, le droit d'auteur, seems to be a term of the past or one romanticized and stuck within the civilian tradition and vanishing from the Canadian common law tradition. ${ }^{218}$ Creators remain subject to industry power imbalances which are facilitated by the CCA (allowing freedom of contract and in practice favouring right holders) and facilitated by the courts (undermining creators, but championing another stakeholder previously ill-addressed, the users). Author-centric provisions may thus be necessary (accounting for the role of contract and moral rights) to balance liberalized fair dealing and potential future exceptions and right holder centric existing provisions. In this context, as an example of eschewing a fragmented fix-it approach, addressing the issue of the various types of damages available and the requisite levels of proof is also an important matter and needs consideration in light of the different types of infringement and infringers.

${ }^{218}$ This was not always the case: D’Agostino En attendant Robertson (n 18). 
And when all is said and done, if copyright balance is found, the next more important question is whether the CCA is clear enough to communicate this balance. Are the CCA's objectives embraced by the practices of stakeholders, the courts and so on? One hindrance may be the lack of clarity in the CCA. Simplifying and clarifying the CCA was flagged as a long term priority in the Section 92 Report and should not to be forgotten in the short term. 